DOI: https://doi.org/10.32653/CH162353-375

Казанский Михаил Михайлович, ведущий научный сотрудник, доктор хабилитат

Национальный центр научных исследований, Франция

michel.kazanski53@gmail.com

\title{
ЭЛЕМЕНТЫ КОНСКОГО СНАРЯЖЕНИЯ ПОСТГУННСКОГО ВРЕМЕНИ HА СЕВЕРНОМ КАВКАЗЕ И ИХ ПАРАЛЛЕЛИ НА ОКРАИНАХ СТЕПИ
}

Аннотация: На памятниках Северного Кавказа для постгуннского времени (т.н. шиповский горизонт, середина V - середина VI вв.) выявлен ряд показательных элементов конского снаряжения - псалии, пряжки, ременные аппликации, металлические накладки на седла. Такие же вещи фиксируются и у оседлых варваров на окраинах кочевой степи. При этом, за исключением седельных накладок, они отсутствуют в погребениях степных кочевников того же времени (гунны, болгары, угры). Тем не менее, представляется, что распространение конского снаряжения является результатом влияния некой «воинской» моды, в первую очередь в среде вождей оседлых варваров, культурно, а может быть и политически ориентированных на кочевую степь. Последнее обстоятельство может обьяснить распространение рассматриваемых в статье предметов конского снаряжения прежде всего в пограничье Великого степного пояса. Речь может идти о варварах, находившихся в союзнических (или подчиненно-союзнических) отношениях со степными кочевниками. В отдельных случаях для Северного Кавказа такая модель напрямую подтверждается письменными источниками. Ряд ярких находок конского снаряжения присходит из некрополя Дюрсо около Новориоссийска, принадлежавшего готам-тетракситам. Как известно, проживавшие в Восточном Крыму готы-тетракситы в середине V в. присоединились к уходившим на восток гуннам и переселились на черноморское побережье Северного Кавказа. На подчиненно-союзническое положение готов-тетракситов по отношению к гуннам-утигурам указывает тот факт, что в ходе последующей войны между утигурами и кутригурами готы должны были выставить в помощь утигурам войско в 2000 бойцов.

Ключевые слова: Северный Кавказ; конское снаряжение; постгуннское время; кочевники; оседлое население; воинская мода

(C) Казанский М.M., 2020

(C) Дагестанский федеральный исследовательский центр РАН, 2020

(@) $\odot$ Creative Commons Attribution 4.0 International License 
DOI: https://doi.org/10.32653/CH162353-375

Kazanski Michel

Research Director, Doctor habilitat, National Center for Scientific Research, France, michel.kazanski53@gmail.com

\section{ELEMENTS OF HORSE EQUIPMENT OF POST-HUNNIC PERIOD IN THE NORTH CAUCASUS AND THEIR VARIANTS ON THE OUTSKIRTS OF THE STEPPE}

Summary: On the archaeological sites of the North Caucasus for the post-Hunnic Period (the socalled horizon of Shupovo, mid-V - mid-VI centuries AD), a number of indicative elements of horse equipment - bits, buckles, strap appliques, and metal appliques for saddles - were revealed. The same things are recorded in settled barbarians on the boundary of the nomadic steppe. Moreover, with the exception of saddle appliques, they are absent in the burials of the steppe nomads of the same time (Huns, Bulgarians, Ugrians). Nevertheless, it seems that the distribution of horse equipment is evidence of the spread of a kind of "military" fashion, primarily in the "leader" environment of sedentary barbarians, culturally, and maybe politically oriented to the nomadic steppe. The latter circumstance can explain the distribution of the things examined here primarily in the borderlands of the Great Steppe Belt. We can talk about barbarians who were in allied (or subordinate-allied) relations with the steppe nomads. In some cases, for the North Caucasus, such a model is directly confirmed by written sources. A number of bright finds of horse equipment come from the necropolis of Diurso near Novorossiysk, which belonged to the Goths - Tetraxites. As it is known, Goths

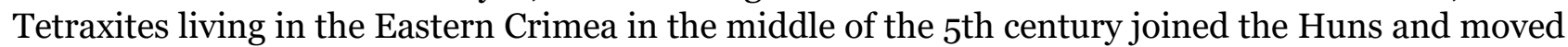
to the Black Sea coast of the North Caucasus. The subordinate-allied position of the Goths-Tetraxites with respect to the Huns-Utigurs is indicated by the fact that during the subsequent war between the Utigurs and Kutrigurs the Goths were supposed to put an army of 2,000 soldiers to help the Utigurs.

Keywords: North Caucasus; horse equipment; post-Hunnic Period; nomads; settled population; military fashion. 
На памятниках Северного Кавказа для постгуннского времени (т.н. шиповский горизонт, середина V - середина VI вв.) выявлен ряд показательных элементов конского снаряжения, таких как некоторые формы псалиев, пряжки, ременные аппликации, накладки на седла из металлических пластин $[1,2]$. В данной работе будут приведены их параллели, лучше всего представленные на окраинах евразийской степи у оседлого населения, и будет предпринята попытка интерпретации их распространения.

\section{Псалии с лопастью и рифленой шейкой}

Псалии с загнутыми верхними концами, украшенными поперечным рифлением или его имитацией на шейке, заканчивающимися полиэдрическими шишечками, реже зоомрфными изображениями и широкой лопастью на другом конце (рис. 1) типичны для памятников Северного Кавказа «шиповского» горизонта [1, p. 529-536; 2, с. 95, 98]. Их возможными прототипами являются похожие псалии гуннского времени [последняя треть IV - середина V в.), вроде найденных в «княжеском» погребениии Унтерзибенбрунн (Untersiebenbrunn) на территории Нижней Австрии [3, Abb. 124, 3; фото: 4, рис. 4, 1,6]. Эти псалии входят в состав «понтийской» узды [по терминологии И.Р. Ахмедова: 5, с. 244-248; 6, с. 160].

На Северном Кавказе (рис. 6) интересующие нас псалии найдены в некрополях Дюрсо, конское погребение 4 [7, Рис. 3, 16], Лермонтовская Скала-2, погребение 10 [8, рис. 4, 5], Мокрая Балка, погребение 119 [9, рис. $137,6]$, а также в Кумбулте и на территории Кабардино-Балкарии (контекст неизвестен) [10, рис. 39, 22,23] (рис. 1, 1-5).

За пределами Северного Кавказа (рис. 6) такие псалии встречены в ЮгоЗападном Крыму, на могильнике Сахарная Головка, погр. 4 (21) [11, рис. 6, 18], в Среднем Поднепровье, в кладе, найденном в Глуховском районе Сумской области, т.е. на территории колочинской раннеславянской культуры [12, рис. 7, 1, 2], на Верхнем Дону, в погр. 1 могильника Ксизово-19, принадлежащего группе памятников типа Чертовицкое-Замятино [13, рис. 201, 17], в Среднем Поволжье, на Новославском могильнике именьковской культуры [14, рис. 3.12] а также далеко на востоке, в Западном Казахстане, на Мангышлаке, в Алынказгане [ограда 158: 15, рис. 13, 11 $]^{1}$ (рис. 1, 6-10). Хронология всех этих

1 К этой же группе псалий И.Р. Ахмедов относит неопубликованные находки с памятников рязано-окской культуры - Заречье-4, погребение 55 и с территории Шиловского района Рязанской обл., а также находку из Восточного Приаралья, из могильника джеты-асарской культуры Алтын-Асар 4, погребение 12 [6, с. 160, 161]. Кроме того, как на Северном Кавказе, так и за его пределами известны похожие псалии, но без рифления или имитирующего рифление декора. Это находки из погребения 4 (14) могильника Лермонтовская Скала-2 [16, рис. 9, 5], Дюрсо, погребение 8 [7, рис. 2, 5], из крепости Цебельда, на территории Абхазии [17, рис. 52,$1 ; 18$, рис. 96,$5 ; 5$, рис. $5,1-3]$ и из могильника ШапкаАхьяцараху, погребение 3 [19, табл. XLIX, 17], из Прикубанья [6, рис. 4], из находки в Климово [12, рис. $5,2,3]$, из клада Гапоново в Среднем Поднепровье [20, рис. 32,1$]$, из Армиевского могильника, погребение 57, из Шокшинского могильника, погребение 94, из могильника Броды на Каме [6, с. 161]. Большую часть этих находок И.Р. Ахмедов относит к поздней группе «понтийской» узды [5, с. 249, 
памятников укладывается в рамки постгуннского времени.

Отметим и находку гуннского времени из «княжеского» кургана 7 в североосетинском могильнике Брут-1, где псалии не имели шишечек на концах и декора на шейке, но у них на лопастях присутствует декор в виде поперечных линий [21, рис. 29а] (рис. 2, 3). Похожие псалии без шишечек, но с декором на лопастях или на шейке, встречены и в погребении 44 абхазского могильника Шапка-Абгыдзраху [19, табл. XXII, 4] (рис. 2, 1), и из балтского могильника самбийско-натангийской культуры Зохпен (Zohpen)-Суворово, погребение 266 (рис. 2, 2), в Восточной Пруссии, т.е. на территории современной Калининградской области [22, fig. 6, 2] ${ }^{2}$. Надо упомянуть и псалиии с рифленым декором из могильника рязано-окской культуры Заречье 4, погребение 2 [23, рис. 2, 1], где шейка, в отличие от других подобных предметов, не округлая в сечении, а плоская (рис. 2, 4).

\section{Цельнолитье пряжки с овальной рамкой и треугольньмк ицикком}

Такие пряжки (рис. 3, 1-44), скорее всего от конской сбруи ${ }^{3}$ хорошо известны на Северном Кавказе. Они имеют позднеримские прототипы, а их дериваты существуют до начала VII в. В гуннское время подобные находки представлены в кладе Сёсдала (Sösdala) в Южной Швеции [4, рис. 1, 11]. Для постгуннского периода показательны находки в могиле Хыныслы с монетой 457-483 гг. (Азербайджан), а также близкой, хотя и не во всем идентичной, находкой в аламаннской могиле Хейлбронн-Бекинген (Heilbronn-Böckingen), конца V в. Поздняя вариация этих пряжек отмечена для 590-620 гг. в погребении 153 аламаннского могильника Сонтхейм (Sontheim) [1, p. 529, 530; 2, c. 98 $]^{4}$.

Для Северного Кавказа назовем находки в Дюрсо, конские погребения 5, 9 и женское погребение 410 [7, рис. 3, 7,8; 24, рис. 8,2]; в Амгате, погребение 1 [25, рис. 9, 10], в Былым-Кудинетово, курган 14 [10, рис. 39, 2], в Лермонтовской Скале-2, погребение 10 [8, рис. 3, 10], в Кугуле, западный склеп 2 [26, рис. 4, 21], в Гижгиде [27, рис. 45, 8], в Тырны-Аузе [28, рис. 2, 2; 29, табл. XX, 11], в Чегеме [28, рис. 2,4], Кичмалке [30, рис. 1, 13], в Тызыле [10, рис. 29, 7], в Харачое [31, рис. 161, 1; 164, 15]. Подобные пряжки были найдены в Приубанье (рис. 3, 1-19), однако контекст и точное место находки неизвестны [6, рис. 2, 5-7].

Вне северокавказского региона такие пряжки известны в Абхазии, в

250, рис. 5], которая, судя по находке в Лермонтовской Скале-2, погребение 4 (14) вместе с ранними стременами [16, рис. 9,6], доживает до VII в. и здесь не рассматривается.

2 Пользуюсь случаем поблагодарить К.Н. Скворцова за любезно предоставленный рисунок этих удил из рукописи Н. Heym, «Das Gräberfeld Zohpen» (Diss.). 1938.

3 Они при этом иногда попадают и в женские погребения, см. напр. Дюрсо, погребение 410 [24, рис. 8,2$]$.

4 Здесь не рассматриваются довольно многочисленные пряжки похожей формы, но с подвижным щитком. 
некрполеЦибилиума,погр.314,ужесвещамиболеепозднего геральдического стиля [32, рис. 146, 33], в Юго-Западном Крыму, на могильнике Сахарная Головка, в том же погр. 4 (21), что и упоминавшиеся выше удила [11, рис. 6, 27], в Херсонесе, где известны незаконченные экземпляры, что свидетельствует о производстве здесь подобных пряжек [33, рис. 38,19$]$, в Керчи [33, рис. 38 , $\left.16 ; 34, \mathrm{~N}^{\circ} 122.1\right]$, а также в Среднем Поднепровье, в составе Глуховского клада [о нём см. выше, 12, рис. 7, 1, 2] и в Киеве (случайная находка) [35, с. 34, рис. $47,2]$, в «вождеском» погребении 110 , могильника рязано-окской культуры Борок-2 [36, рис. 4,1-3], в разрушенном погребении другого окского могильника, Ундрих [37, рис. 9, 3], а также в уже упоминавшемся окском погребении 55 могильника Заречье 4 [23, рис. 2, 14, 15], в Подболотьевском могильнике, погребение 185 [29, табл. XII, 6], и в Среднем Поволжье, на Островном I селище Щербеть, именьковской культуры [38, табл. 19,8], на Южном Урале, в Бирском могильнике погребение 138 (?), 156 [10, рис. 33, 5, $11,14 ; 35,16,17]$ и, наконец, в низовьях Сыр-Дарьи, на памятниках джетыасарской культуры Косасар-3, погребение 11 [39, рис. 20, 7], Алтынасар-4, курганы 68, 313, [40, рис. 149, 15, 16, 151, 31-33] (рис. 3, 20-44).

\section{Сегментовидные сбруйные накладки}

Эти аппликации вытянуто-полукруглой формы, часто украшенные гранатовыми (и стеклянными?) вставками и в ряде случае с декором в виде поперечного рифления на нижнем крае (рис. $3,45-55$ ), также являются показательными для памятников Северного Кавказа постгуннского времени [2, с. 95]. На Северном Кавказе они найдены в могильниках Лермонтовская Скала-1, погребение 6 [41, рис. 8,5; 42, рис. 2, 1], Лермонтовская Скала -2, погребение 10 [8, рис. 3,5$]$, Развалка [26, рис. 1,4$]$. Надо упомянуть и уже цитированую находку из Прикубанья $[6$, рис. $2,1,2]$ (рис. $3,45-49$ ).

В других регионах Восточной Европы такие накладки встречены в Крыму, всё в том же погребении 4 (21) могильника Сахарная Головка [11, рис. 6, 3o], а также в Керчи $[1$, fig. 8,$3 ; 2$, рис. 6,10$]$ и в уже упоминавшемся погребении 110 окского могильника Борок-II [36, рис. 4, 8-11] (рис. 3, 5o-55).

\section{Металлические накладки на седла}

Среди хроноиндикаторов постгуннского времени на Северном Кавказе одними из наиболее ярких являются металлические накладки на седла сегментовидной и треугольной формы [2, с. 93-95; 43] (рис. 4, 5, 7). Эта категория предметов специально изучалась И.П. Засецкой и И.Р. Ахмедовым, типологии которых здесь и используются $[44,45,46]$. В северокавказском контексте известно три типа накладок, соотносимых с шиповским горизонтом.

Прежде всего это сегментовидные «высокие» накладки подтреугольной 
формы с сильно выгнутой боковой стороной типа Засецкая 3-Ахмедов 3 [44, с. 46, Приложение 3, № 10, Рис. 9, 4; 45, с. 144, 145; 46, с. 23] (рис. 4, 1-6). Они встречаются не часто. На Северном Кавказе они найдены в могильниках Лермонтовская Скала-2, погребение 10 [8, рис. 6, 1], где известна целая форма, и, вероятно, Лермонтовская Скала 1, погребение 3 [47, рис. 9, 14], где сохранился лишь фрагмент с характерным декором [46, с. 23]. За пределами Кавказа мне известна лишь одна находка близкой по форме накладки, на Мангышлаке, в Алтынказгане, в ритуальном захоронении на ограде 15 [15, рис. 11,$7 ; 48$, рис. 10,1$]$.

Сегментовидные «низкие» накладки типа Засецкая 4а,б-Ахмедов 3 а-4 [44, Приложение 3, № 11, 12-14, 16; 45, с. 145; 46, с. 23-25] (рис. 4, 7-11) распространены шире. Они найдены на Северном Кавказе в Дюрсо, конские погребения 4, 9, 10 [7, рис. 4, 1,3,4 $]^{5}$, и, вероятно в Мокрой Балке, в уже упоминавшемся в связи с псалиями погребении 119 [9, рис. 137, 7]. Здесь сохранился лишь фрагмент, отнесенный И.Р. Ахмедовым по характеру декора к этому типу [46, с. 23]. Параллели этим накладкам известны в степной зоне, в Шипово, погребение 3 [44, табл. 41, 8] и в Ольвии [44, рис. 10, 11, Приложение 3, № 11], в Среднем Поднепровье, в курганной находке около сел. Бабичи $[12$, рис. 9, 1], на Урале, в находке в Уфе, на ул. Тукаева (сохранился фрагмент, идентификация И.Р. Ахмедова по декору) [10, рис. $34,8,9 ; 46$, с. 23$]$ и в Западном Казахстане, в Алтынказгане [15, рис. 11, 6].

Сегментовидные «низкие» вытянутые накладки типа Засецкая 4в-Ахмедов 6 [44, Приложение 3, № 15, 17-19; 45, с. 145; 46, с. 26] (рис. 4, 1217) на Северном Кавказе найдены в Дюрсо, в конском погребении 5 [7, рис. $4,3]$ и в Галайты $[43 ; 49 \text {, рис. } 2,1]^{6}$. Параллели им известны в Керчи [44, рис. 10, 17, Приложение 3, № 17], а также в Западной и Центральной Европе, в меровингском погребении 1782 Крефельд-Геллеп (Krefeld-Gepllep) [50, fig. 15,4; 51, Kat. V.4.8, Abb. 192-196]7 , в Равенне [52, Taf. XXX] и в Шарвиз (Sárvíz) [53, Taf. IX; 54] ${ }^{8}$. На Северном Кавказе подобные накладки существовали и позже, как показывает, например, находка в одном из курганов Чир-Юрта (Северный Дагестан) с монетой 582-602 гг. [10, рис. 41, 10; 55, рис. 23] (рис. $4,17)$. Впрочем, согласно И.Р. Ахмедову, пластина их Чир-Юрта не связана с его группой 6 [46, с. 29].

Треугольные накладки вытянутой формы, типа Засецкая тип 1б-

5 Накладка из конского погребения 10 также очень напоминает только что цитированную находку из погребения 10 могильника Лермонтовская Скала-2.

6 По мнению А.К. Амброза, подобные накладки были найдены и в Преградной. на Кубани, вместе с вещами геральдического стиля. т.е. второй половины VI-VII вв. [10, рис. 37, 1-21]. Однако предметы не сохранились и судить об их форме невозможно.

7 Эта находка имеет особое значение для датировки пластин данного типа. Могила меровингского «вождя» принадлежит к фазе II раннемеровингских древностей, то есть ко второй трети VI в., и датируется, по аналогии с «княжеским» захоронением мальчика в Кёльне [51, Kat. VI.2.2, Abb. 346349], начальной стадией указанной фазы. Дата кёльнского погребения определяется, в свою очередь, по дендрохронологии в пределах от 527 по 547 гг. [50, p. 250].

8 По И.Р. Ахмедову западные накладки представляют собой особый тип 7 [46, с. 26]. И.П. Засецкая их в отдельный тип не выделяет. 
Ахмедов 5 [45, с. $143 ; 46$, с. 25,26$]$ (рис. 5) известны на Северном Кавказе в Галайты $[43,49$, рис. 2, 10, 11]. Их параллели известны в степных находках постгуннского времени, в Ялпуге, на Нижнем Дунае [56] и во Владимирском могильнике, курган 4, погр. 2, в Самарском Поволжье [44, табл. 35, 13], а также в Керчи [46, рис. 3], в Среднем Поволжье, в могильнике Коминтерн, погр. 46, возможно, погр. 42 [57, рис. 30, 8, 36, 4] ${ }^{9}$, на Южном Урале, в Слончанке I [58, рис. $25,13,14]$, и далее на восток, в Казахстане, в Боровом $[59$, Taf. 51, 12]. Эти накладки появляются еще в гуннское время, как об этом свидетельствуют находки в Солончанке I, курган 1 (видимо поминальник), поскольку там были найдены типичные для гуннского времени пряжки [58, рис. 23, 1-3] характерные для периодов D2 [380/400-440/450 гг.) и D2/ D3 (430/440-460/470 гг.), по хронологии европейского Барбарикума. Ряд других находок, таких как Ялпуг и Владимирский, датируются постгуннским временем, а находки в Коминтерн соответствуют переходу от шиповского горизонта к горизонту геральдических поясов, т.е. скорее всего второй трети VI в. [см. подробнее 56, там же библиография].

$$
* * *
$$

Итак, мы можем констатировать, что у населения Северного Кавказа в постгуннское время, распространяется ряд элементов конского снаряжения - псалии, пряжки, ременные апликации, седельные накладки, которые фиксируются и у оседлых варваров на окраинах кочевой степи (рис. 6, 7). При этом, за исключением седельных накладок эти вещи остутствуют в погребениях степных кочевников шиповского [постгуннского) горизонта [гунны, болгары, угры). Возможно, такая ситуация обьясняется недостаточной изученностью древностей середины V - середины VI вв., поскольку на сегоднящний день в научный оборот введено всего около 25 «кочевнических» памятников постгуннского времени [см. 60, рис. $14-$ карта памятников].

Показательно, однако, что похожая ситуация наблюдается и с распространением элементов женского убора того же времени - ряд украшений и элементов костюма фиксируется у оседлых соседей степных кочевников на Северном Кавказе, в Крыму, в Среднем Поднепровье, на Верхнем Дону, в Среднем и Нижнем Поволжье, на Южном Урале и даже в низовьях Сыр-Дарьи, но при этом они крайне редки или полностью отсутствуют у степняков [61]. Как известно, в традиционных обществах предметы женского убора, за исключением некоторых компонентов (бусы), не являются предметом купли-продажи, они могут распространяться либо вместе с их носительницами, либо в результате постепенного влияния моды - последнее обстоятельство, впрочем, предполагает устойчивиые контакты между различными варварскими народами степного пограничья,

9 Интересно отметить, что погребения содержали по степному обычаю кости ног и череп (т.е. шкура) лошади: см. 57. 
от Аральского моря до Дуная, что крайне маловероятно для постгуннской эпохи. Распространение женского убора, несомненно, отражает какие-то связи оседлых варваров степного пограничья с кочевниками и, возможно, является свидетельством перемещения (депортации) каких-то групп оседлого населения [61].

Что касается конского снаряжения, зачастую связанного с престижным контекстом археологических находок, то оно, на мой взгляд, скорее является свидетельством распространения некой «воинской» моды, в первую очередь в «вождеской» среде, культурно, а может быть и политически ориентированной на кочевую степь. Последнее обстоятельство и может обьяснить появление рассмотренных здесь вещей прежде всего в пограничье Великого степного пояса. Речь может идти о варварах, находившихся в союзнических (или подчиненно-союзнических) отношениях со степными кочевниками ${ }^{10}$.

В отдельных случаях для Северного Кавказа такая модель напрямую подтверждается письменными источниками. Как мы видели, ряд ярких находок конского снаряжения присходит из причерноморского некрополя Дюрсо, принадлежность которого готам-тетракситам признается всеми специалистами, по крайней мерее в том, что касается ранней фазы некрополя (середина V - середина VI в.). Как нам известно, благодаря Прокопию Кесарийскому, проживавшие в Восточном Крыму готы-тетракситы в середине V в. (после 429 г.) присоединились к уходившим на восток гуннам и переселились на черноморское побережье Северного Кавказа. Около 547 г. посольство готов-тетракситов появляется в Константинополе с просьбой о назначении им нового епископа. От них Прокопий и получает подробную информацию об этом народе [62, IV. 4, 5]. На подчиненно-союзническое положение готов-тетракситов по отношению к гуннам-утигурам указывает тот факт, что в ходе последующей войны между утигурами и кутригурами готы должны были выставить в помощь утигурам войско в 2000 бойцов [62, IV. 18].

Для интересующего нас времени можно напомнить и факт подчинения германцев-ангискиров сыновьям Аттилы в эпоху после битвы при Недао в 454 г. [Иордан, § 272] или же совместное нападение гуннов и склавинов на балкано-дунайские провинции Византии в 558-559 гг., хотя в последнем случае у нас нет никакой информации о характере союзнических отношений между этими варварами [Иоанн Малала. 490. 6-12, цит. 64, с. 268; Феофан, I, цит. 65, с. 253] или же, наконец, совместную службу гуннов, антов и склавинов в конном корпусе Мартина и Валериана в 536 г. во время Готской войны в Италии [62, I. 27]. Подобные события, вне всякого сомнения, способствовали распространению единой престижной воинской моды у самых различных варваров на пограничье степи.

10 В качестве рабочей гипотезы, нуждаюшейся в проверке и подтверждении, можно предположить, что «статусный» набор воинских предводителей оседлых варваров, находившихся в союзных отношениях с кочевниками-степняками, отличался от престижного набора степных владык, что обьясняет отсутствие ряда рассмотренных здесь предметов конского убора в степном контексте. 


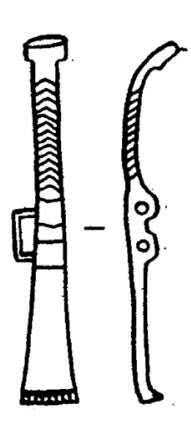

1

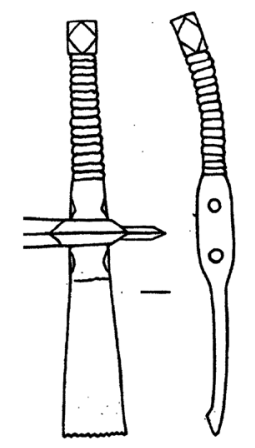

2

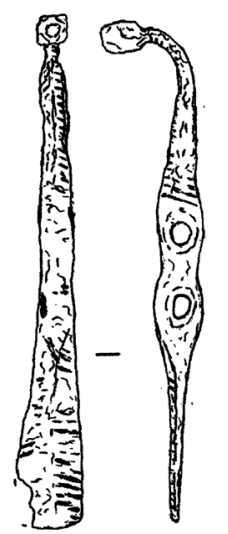

6

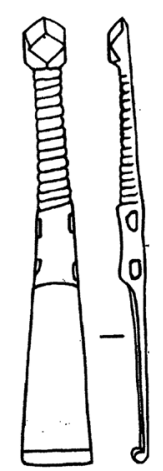

3

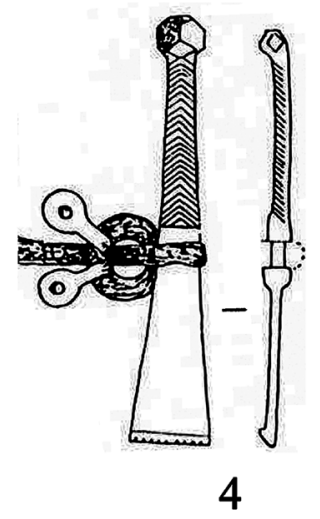

4
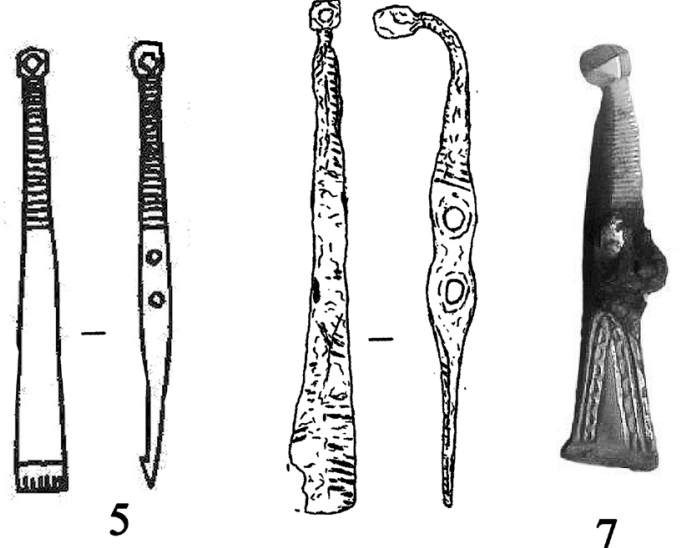

7
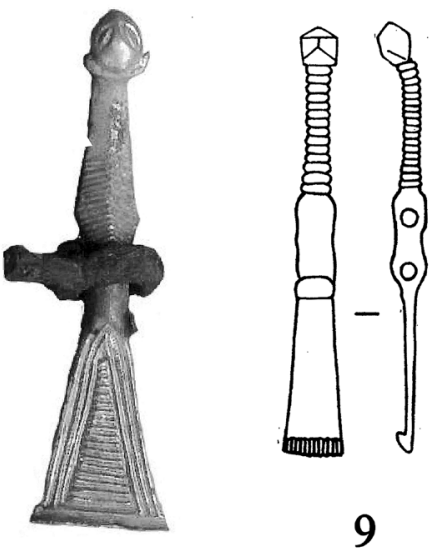

9

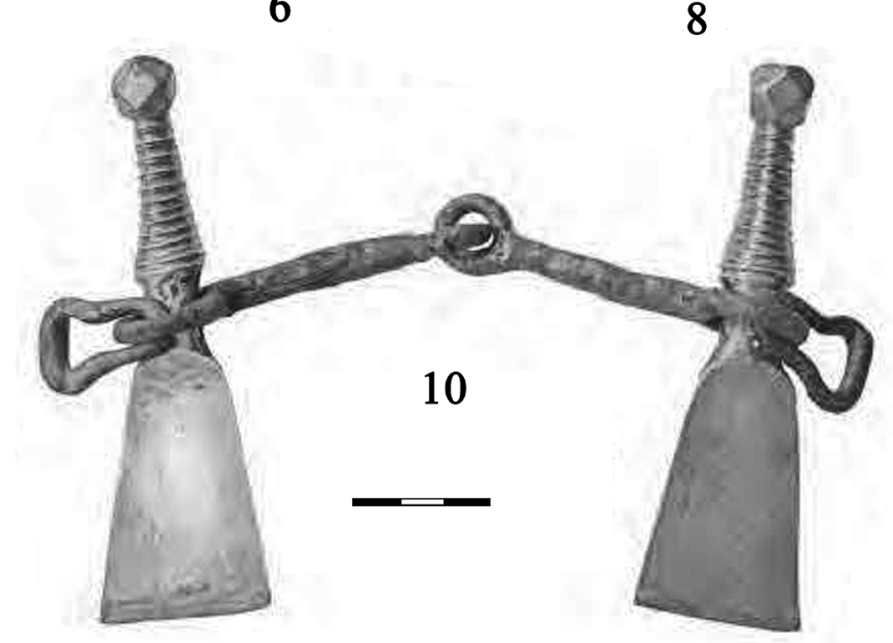

Рис. 1. Псалии с лопастью и рифленой шейкой.

1: Дюрсо, конское погребение 4; 2: Кумбулта; 3: Кабардино-Балкария; 4: Лермонтовская Скала-2, погребение 10; 5: Мокрая Балка, погребение 119.; 6: Ксизово-19, погребение 1; 7, 8: Глуховский район; 9: Сахарная Головка; 10: Алтынказган, ограда 158.

1: по 7, рис. 3,$16 ; 2:$ по 10, рис. 39,$22 ; 3$ : по 10, рис. 39,$23 ; 4:$ по 8 , рис. 4, 5; 5: по 9, рис. 137, 6; 6: по 13, рис. 201,$17 ; 7,8:$ по 12, рис. 7,1,2; 9: по 15, рис. 13,11

Fig. 1. Bits with a lobe, grooved neck and a bumps at the end.

1: Djurso, horse burial 4; 2: Kumbulta; 3: Kabardino-Balkaria; 4: Lermontovskaja Skala -2, burial 10; 5: Mokraja Balka, burial 119; 6: Ksizovo-19, burial 1; 7, 8: district of Gluhov; 9: Sakharnaja Golovka; 10: Altynkazgan, fence 158.

1: by 7 , fig. 3 , 16; 2 : 10, fig. 39, 22; 3: 10, fig. 39, 23; 4: 8, fig. 4, $5 ; 5$ : by 9 , fig. 137,6 ; 6 : by 13 , fig. 201, 17; 7, 8: 12, fig. 7.1.2; 9: by 15, fig. 13,11 . 

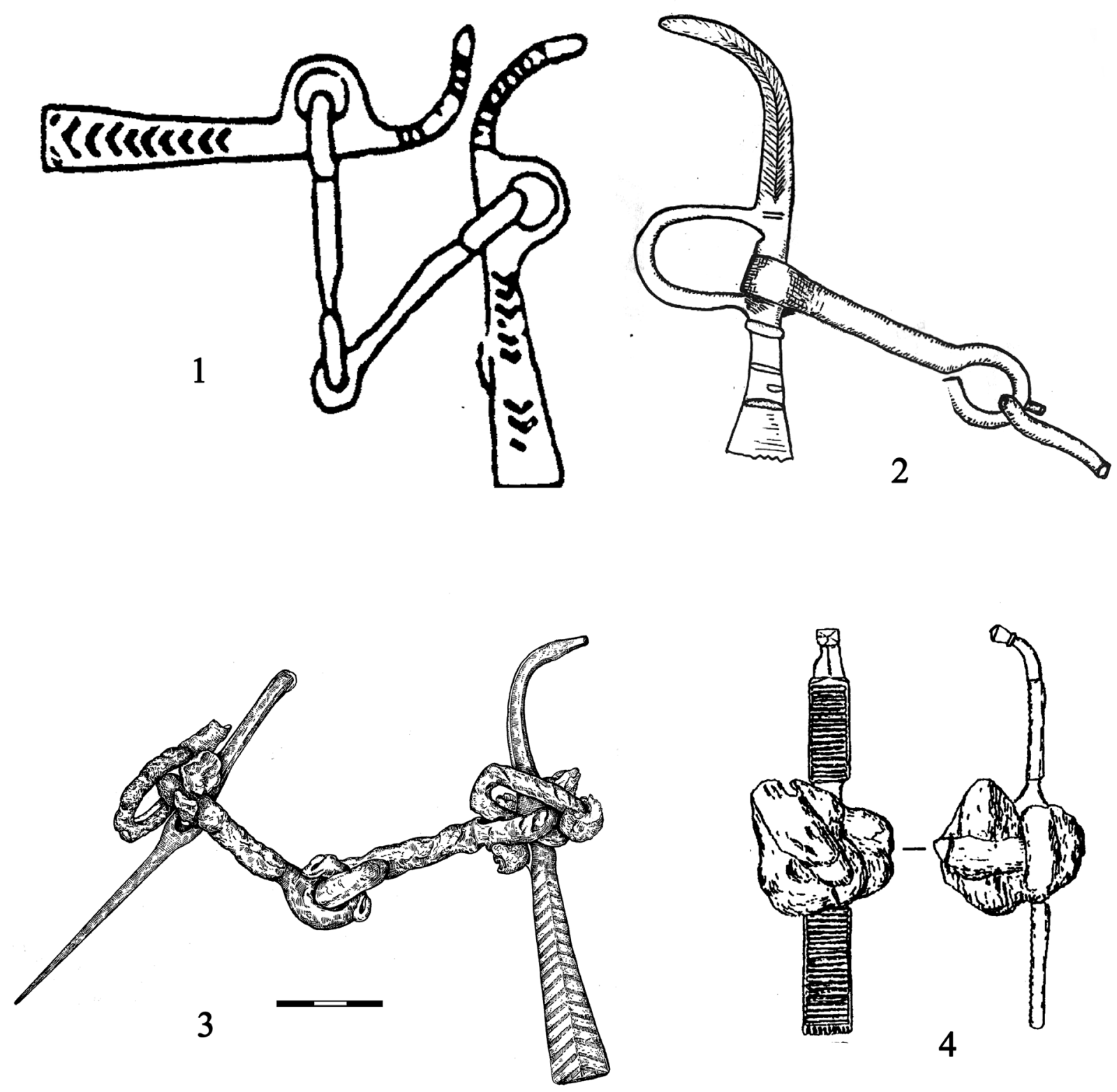

Рис. 2. Псалии с лопастью и рифленым декором или его имитиаций.

1: Шапка-Абгыдзраху, погребение 44; 2: Зохпен-Суворово, погребение 266; 3: Брут-1, курган 7; Заречье 4, погребение 2.

1: по 19, табл. XXII, 4; 2: по 21, рис. 29a; 3: по рисунку X. Хейма; 4: по 23, рис. $2,1$. 2 - без масштаба

Fig. 2. Biths with a with a lobe and grooved decor or its imitations.

1: Shapka-Abgydzrahu, burial 44; 2: Zohpen - Suvorovo, burial 266; 3: Brut -1, mound 7; Zaretchie 4, burial 2. 1: 19, tab. XXII, 4; 2: by 21, fig. 29a; 3: according to the drawing of H. Heim; 4: 23, fig. 2, 1. 2 - no scale 


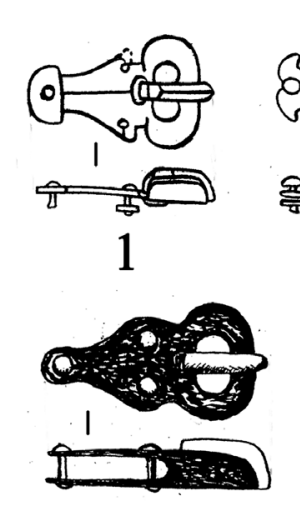

8

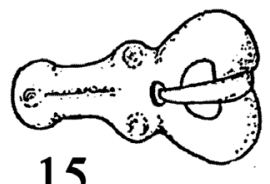

15

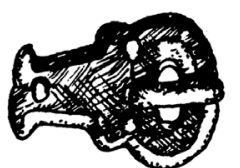

20

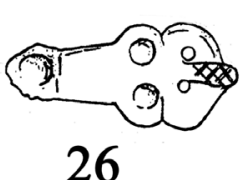

26

(2)

33

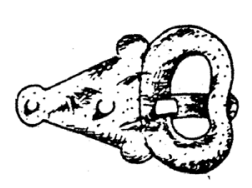

I

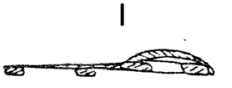

39

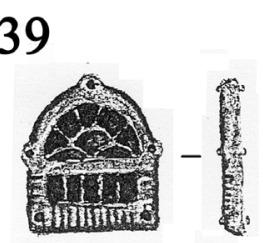

45

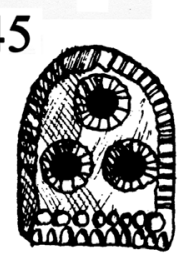

50
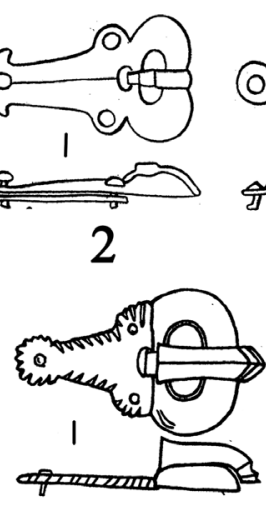

9
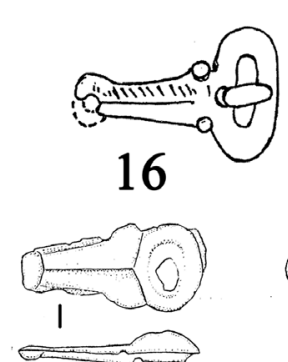

21

(4)
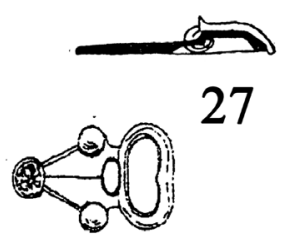

1

34

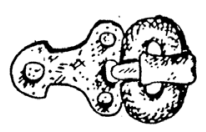

1 - 10

40

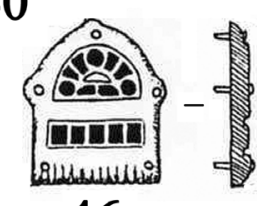
46
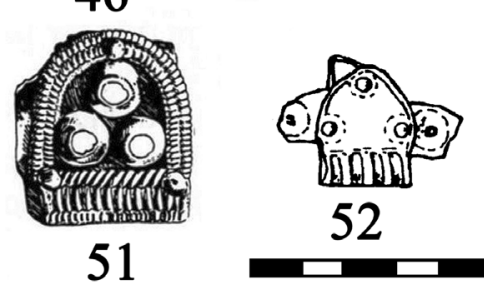

3

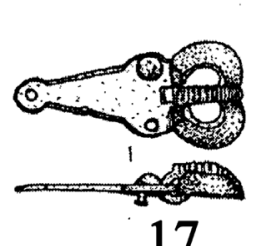

on

22

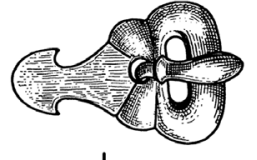

35

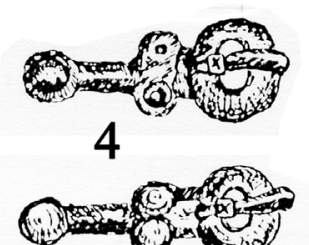

(9)
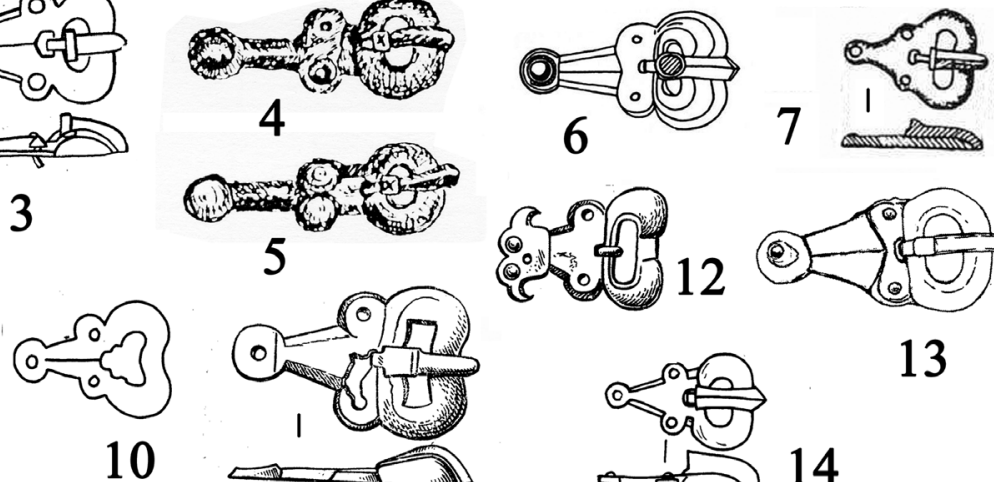

की

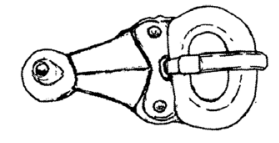

13
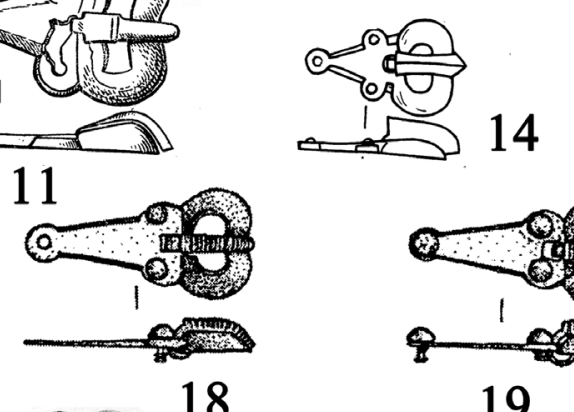

23

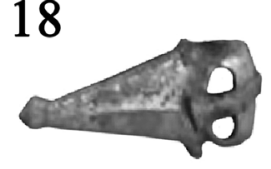

24

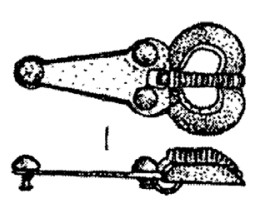

19

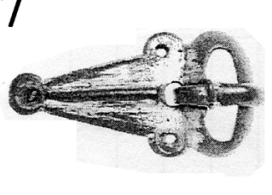

बैंक की

$28 \quad 29$

क्वर

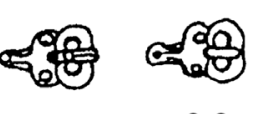

30

$31 \quad 32$

(2)

वीजि

हैजि

37

38

\%

I

का

41

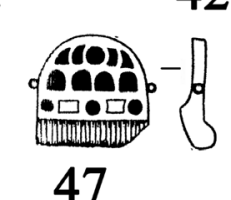

90

OPि

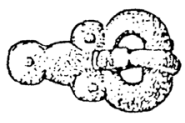

1 다요

42

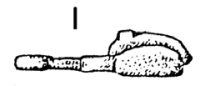

1

44

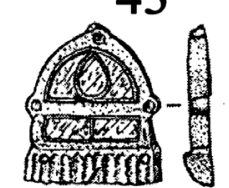

48

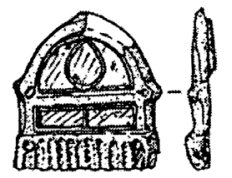

49

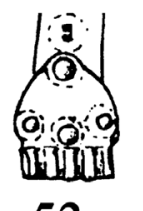

范

54 
Рис. 3. Цельнолитые пряжки с овальной рамкой и треугольным щитком (1-43) и сегментовидные сбруйные накладки (44-54).

1: Дюро, погребение 410; 2: Дюрсо, конское погребение 9;

3: Дюрсо конское погребение 5; 4,5: Амгата; 6: Былым-Кудинетово, курган 14; 7: Лермонтовская Скала-2, погребение 10; 8: Кугуль, западный склеп 2; 9, 10: Гижгид; 11: Тырны-Ауз; 12: Чегем; 13: Кичмалка; 14: Тызыл; 15, 16: Харачой; 17-19, 48, 49: Прикубанье; 20, 50: Сахарная Головка, погребение 4 (21); 21: Херсонес; 22, 23: Керчь; 24,25: Глуховский район, клад; 26: Киев; 27: Цибилиум, погребение 314; 28-30, 52-55: Борок-2, погребение 110; 31, 32: Ундрих; 33, 34: Заречье 4, погребение 55; 35: Подболотье, погребение 185; 36: Щербеть; 37, 38: Бирск, погребение 156; 39: Косасар-3, погребение 11; 40: Алтынасар-4, курган 313; 41-44: Алтынасар-4, курган 68; 45: Лермонтовская Скала-1, погребение 6; 46: Лермонтовская Скала -2, погребение 10; 47: Развалка; 51: Керчь.

1: по 24, рис. 8 , 2; 2: по 7, рис. 3, 7; 3: 7, рис. 3 , 8; 4, 5: по 25, рис. 9, 10; 6: по 10, рис. 39, 2; 7: по 8 , рис. 3,10 ; 8: по 26, рис. 4 , 21; 9,10: по 27 , рис. 45,8 ; 10, рис. 29 , 24 ; 11 : по 28 , рис. 2 , 2 ;

12: 28 , рис. 2 , 4; 13: 30, рис. 1, 13; 14: по 10, рис. 29,7 ; 15, 16: по 31, рис. 161,$1 ; 164,15$;

17-19, 48, 49: по 6, рис. 2, 1, 2, 5-7; 20: по 11, рис. 6, 27, 30; 21: по 33, рис. 38 , 19;

22, 23: по 33, рис. 38,$16 ; 34, \mathrm{~N}^{\circ} 122.1 ; 24,25$ : по 12, рис. $7,1,2$; 26: по 35, рис. 47.2;

27: по 32, рис. 146,$33 ; 28-30,52-55$ : по 6 , рис. 4, 1-3, 8-11; 31, 32: по 37, рис. 9, 3 ;

33, 34: по 23, рис. 2, 14, 15; 35: по 29, табл. XII, 6; 36: по 38, табл. 19,8; 37,38: по 10, рис. 35, 16, 17; 39: по 39, рис. 20, 7; 40: по 40, рис. 149, 16; 41: по 40, рис. 149, 15; 42-44: по 40, рис. 151, 31-33; 45: по 41, рис. 8, 5; 46: по 8, рис. 3 , 5; 47: по 26, рис. 1 , 4; 51: по 2, рис. 6 , 10. $23-26,33,34,51$ - без масштаба

Fig. 3. One-piece buckles with an oval frame and a triangular shield (1-43) and segment-shaped harness appliques (44-54). 1: Djuro, burial 410; 2: Djurso, horse burial 9;

3: Djurso horse burial 5; 4.5: Amgata; 6: According to Bylym Kudinetovo, barrow 14; 7: Lermontovskaja Skala-2, burial 10; 8: Kugul, western crypt 2;

9, 10: Gijguid; 11: Tyrny - Auz; 12: Chegem; 13: Kichmalka; 14: Tyzyl; 15, 16: Harachoy; 17-19, 48, 49: region of Kuban; 20, 50: Sakharnaja Golovka, burial 4 (21); 21: Chersonesos;

22, 23: Kerch; 24.25: district of Glukhov, treasure; 26: Kiev; 27: Cybilium, burial 314; 28-30, 52-55: Borok-2, burial 110; 31, 32: Undrich; 33, 34: Zaretchie 4, burial 55; 35: Podbolotie, burial 185; 36: Sherbet; 37, 38: Birsk, burial 156;

39: Kosasar-3, burial 11; 40: Altinasar-4, barrow 313; 41-44: Altinasar-4, barrow 68; 45: Lermontovskaja Skala-1, burial 6; 46: Lermontovskaja Skala -2, burial 10; 47: Razvalka; 51: Kerch.

1: by 24 , fig. 8.2 ; 2: by 7 , fig. 3,$7 ; 3$ : by 7 , fig. 3 , 8 ; by 4,5 : by 25 , fig. 9,10 ; 6 : by 10 , fig. 39,2 ; 7 : by 8 , fig. 3,10 ; 8 : by 26 , fig. 4 , 21; 9.10 : by 27 , fig. 45,8 ; 10 , fig. $29.24 ; 11$ : by 28 , fig. 2 , 2 ; 12: by 28 , fig. 2.4 ; 13: by fig. 1,13 ; 14 : by 10 , fig. 29,$7 ; 15$, 16: by 31 , fig. 161,$1 ; 164,15$; 17-19,48,49: by 6 , fig. $2,1,2,5-7$; 20 : by 11 , fig. $6,27.30$; 21 : by 33 , fig. 38,19 ; 22, 23 : by 33 , fig. 38,$16 ; 34, \mathrm{~N}^{\circ} 122.1 ; 24.25$ : by 12 , fig. $7,1.2 ; 26$ : by 35 , fig. 47.2 ; 27: by 32 , fig. 146,33 ; $28-30,52-55$ : by 6 , fig. $4,1-3.8-11 ; 31.32$ : by 37 , fig. 9,3 ;

33, 34: by 23 , fig. $2,14,15 ; 35$ : by 29 , tab. XII, $6 ; 36$ : by 38 , tab. $19.8 ; 37.38$ : by 10 , fig. $35.16 .16 ; 39$ : by each 39, fig. 20, 7 ; 40 : by 40 , fig. 149,16 ; 41: by 40 , fig. 149,15 ; 42-44: by 40, fig. 151, 31-33;

45 : by 41 , fig. $8.5 ; 46$ : by 8 , fig. 3,$5 ; 47$ : by 26 , fig. $14 ; 51$ : by 2 , fig. 6.10 . $23-26,33,34,51$ - no scale 

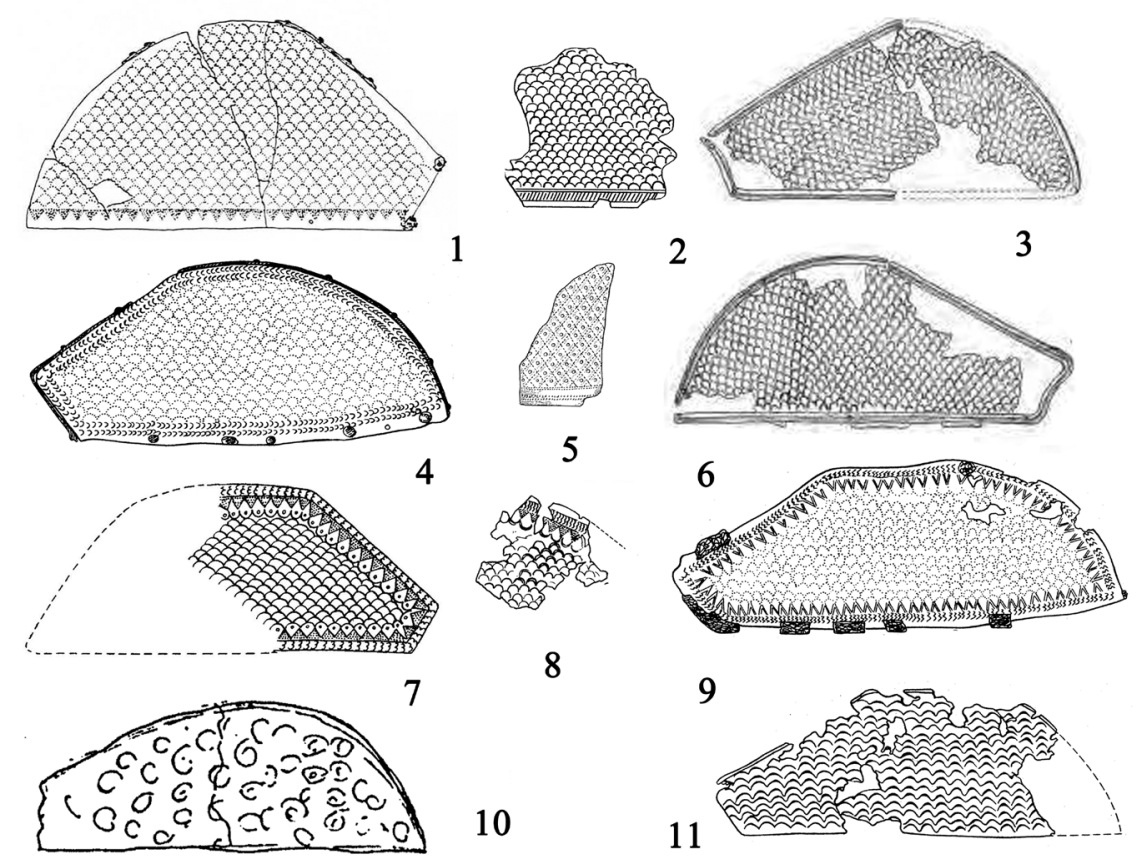

8
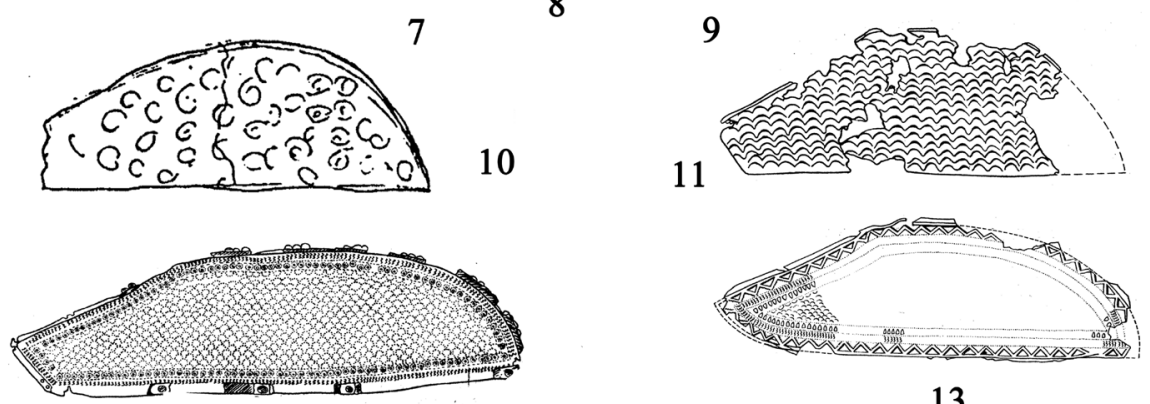

13

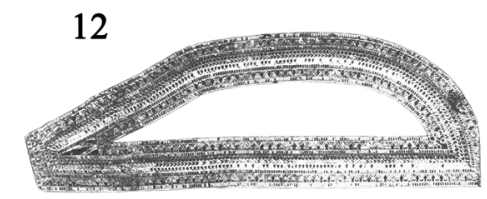

14
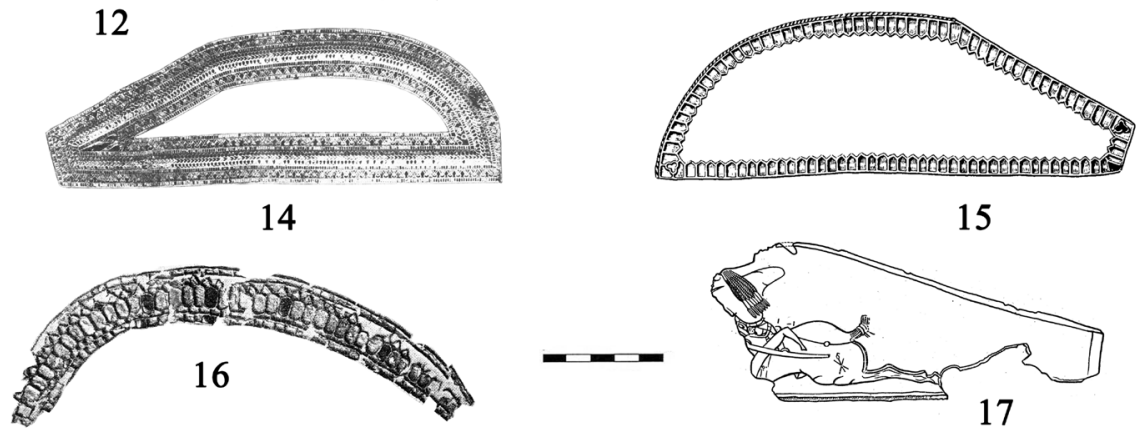

15

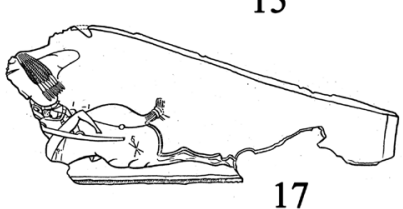

Рис. 4. Сегментовидные металлические накладки на седла.

1: Лермонтовская Скала-2, погребение 10; 2: Лермонтовская Скала-1, погребение 3; 3, 6: Алтынказган; 4: Дюрсо, конское погребение 10; 5: Мокрая Балка, погребение 119; 7: Шипово, погребение 3;

8: Уфа - ул. Тукаева; 9: Дюрсо, конское погребение 9; 10: Бабичи; 11: Дюрсо, конское погребение 4;

12: Дюрсо, конское погребение 5; 13: Галайты; 14: Равенна;

15: Крефельд-Геллеп, погребение 1782; 16: Шарвиз; 17: Чир-Юрт.

1: по 8, рис. 6,1 ; 2: по 27, рис. 19, 9; 3, 6: по 15, рис. $11,6,7 ; 4$ : по 7, рис. 4, 4; 5: по 9, рис. 137, 7;

7: по 44, табл. 41, 8; 8: по 10, рис. 34, 8, 9; 9: по 7, рис. 4, 2; 10: по 12, рис. 9, 1; 11: по 7, рис. 4, 1; 12: по по 7, рис. 4, 3; 13: по 49, рис. 2, 1; 14: по 52, Taf. XXX; 15: по 50, fig. 15,4; 16: по 53, Taf. IX; 17: по 55, рис. $23 ; 16$ - без масштаба.

Fig. 4. Segmented metal appliques on the saddles.

1: Lermontovskaja Skala - 2, burial 10; 2: Lermontovskaja Skala - 1, burial 3; 3.6: Altynkazgan;

4: Djurso, horse burial 10; 5: Mokraja Balka, burial 119; 7: Shipovo, burial 3;

8: Ufa - st. Tukaev; 9: Djurso, horse burial 9; 10: Babichi; 11: Djurso, horse burial 4;

12: Djurso, horse burial 5; 13: Galayty; 14: Ravenna;

15: Krefeld-Gellep, burial 1782; 16: Sarviz; 17: Chir-Yurt.

1: by 8 , fig. 6,$1 ; 2$ : by 27 , fig. $19.9 ; 3.6$ : by 15 , fig. $11.6 .7 ; 4$ : by 7 , fig. 4 , $4 ; 5$ : by 9 , fig. 137,7 ;

7: by 44 , tab. 41,$8 ; 8$ : by 10, fig. $34,8.9 ; 9$ : by 7 , fig. 4,$2 ; 10$ : by 12 , fig. 9,$1 ; 11$ : by 7 , fig. 4,1 ;

12: by 7 , fig. 4 , 3 ; 13 : by 49 , fig. 2,1 ; 14 : by 52 , Taf. XXX; 15 : by 50 , fig. 15,$4 ; 16$ : by 53 , Taf. IX;

17: by 55 , fig. $23 ; 16$ - no scale 

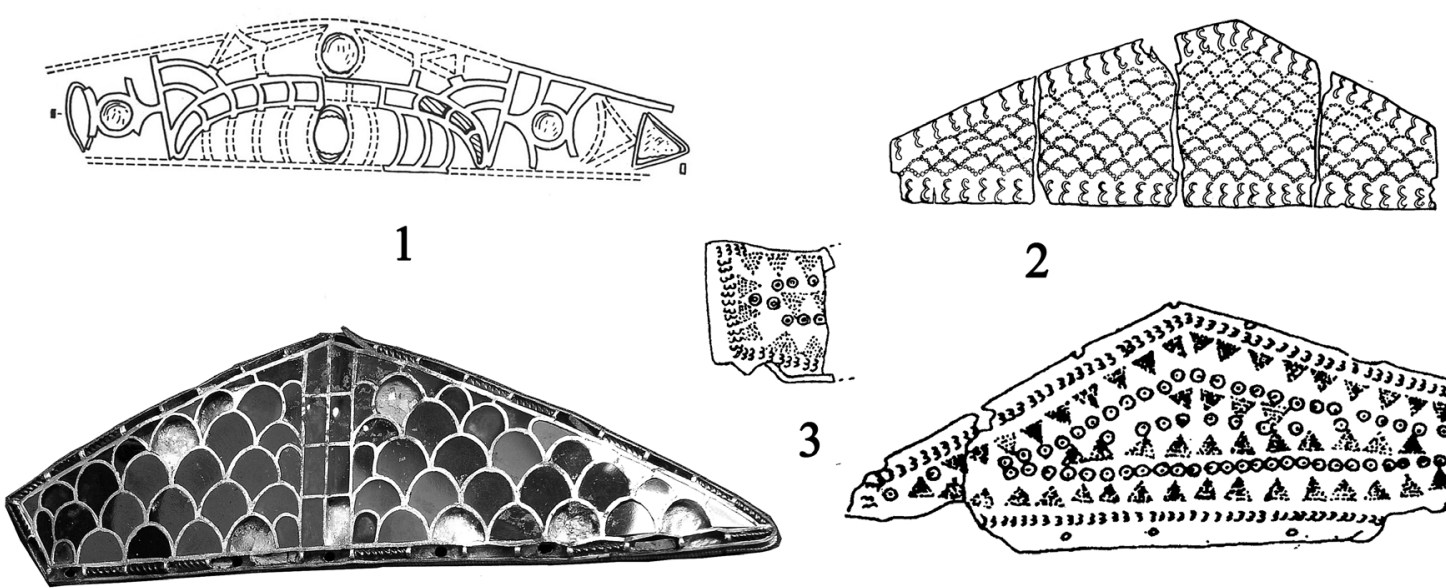

2

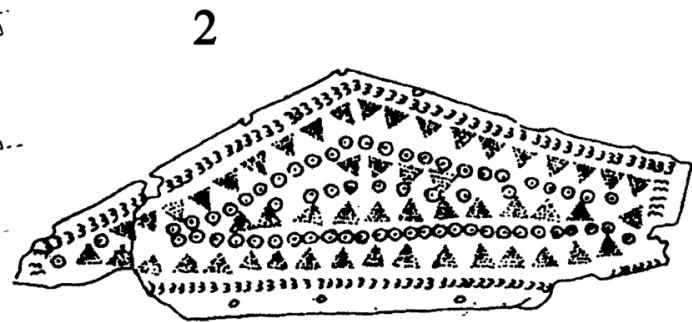

5
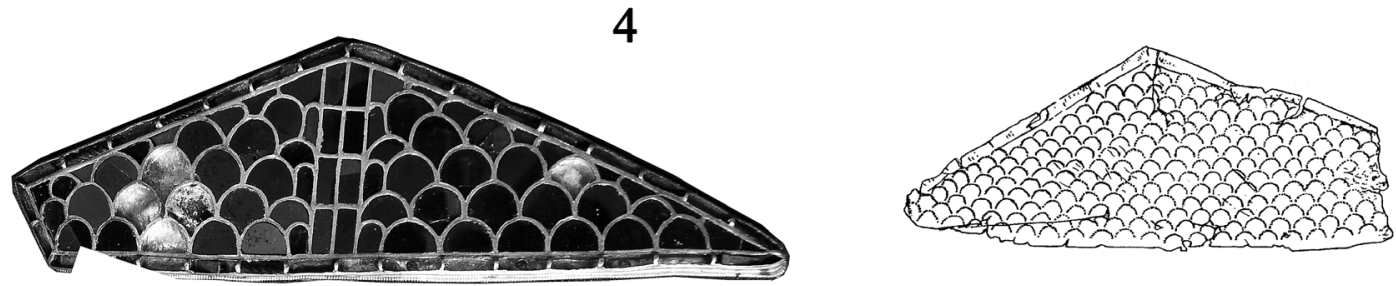

7
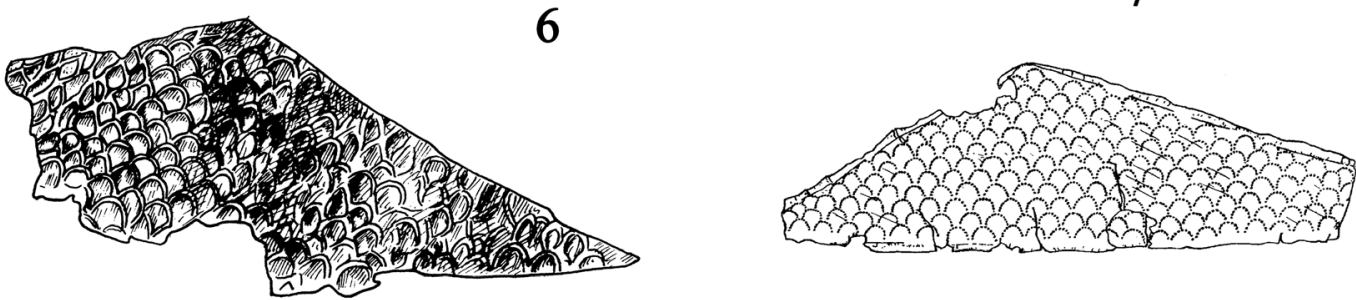

8

9

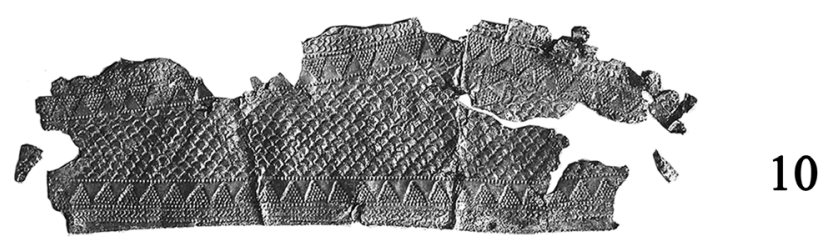

Рис. 5. Треугольные металлические накладки на седла.

1: Галайты; 2: Владимирское, курган 4, погребение 2; 3: Коминтерн, погребение 42;

4, 6: Ялпуг; 5: Коминтерн, погребение 46; 7, 9: Солончанка I; 8: Боровое; 10: Керчь.

1: по 49, рис. 2, 10, 11; 2: по 44, табл. 35, 13; 3: по 57, рис. 30, 8; 4, 6: по 56, fig. 2; 5: 57, рис. 36, 4; 7, 9: по 58, рис. 25, 13,14; 8: по 59, Taf. 51, 12; по 46, рис. 3 . 10 - без масштаба.

Fig. 5. Triangular metal appliques for saddles.

1: Gality; 2: Vladimirskoye, mound 4, burial 2; 3: Komintern, burial 42;

4, 6: Yalpug; 5: Komintern, burial 46; 7, 9: Solonchanka I; 8: Borovoe; 10: Kerch.

1: by 49 , fig. $2,10,11 ; 2$ : by $44,35,13 ; 3$ : by 57 , fig. 30,$8 ; 4$, 6 : by 56 , fig. $2 ; 5:$ by 57 , fig. 36,4 ; 7 , 9: by 58 , fig. $25,13.14$; 8 : by 59 , Taf. 51,12 ; by 46 , Fig. 3 .

$$
10 \text { - no scale }
$$




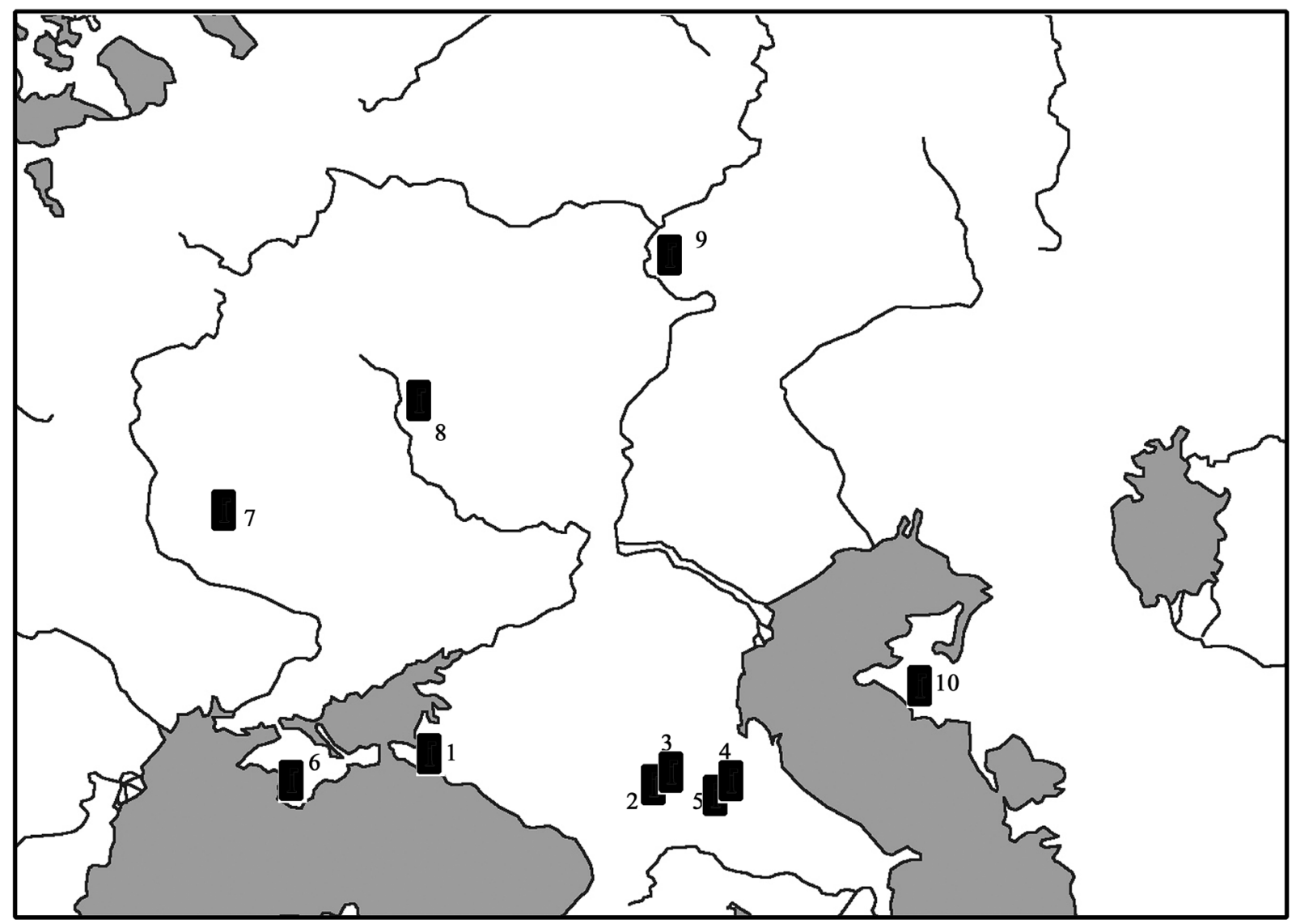

Рис. 6. Карта распространения псалий с лопастями, рифленым декором и шишечками на конце. 1: Дюрсо; 2: Лермонтовская Скала; 3: Мокрая Балка; 4: Кумбулта; 5: Кабардино-Балкария; 6: Сахарная Головка; 7: Глуховский район; 8: Ксизово; 9: Новославка 10: Алынказган. Ввиду масштаба карты локализация памятников приблизительна.

Fig. 6. Map of the distribution of bits with lobes, corrugated decor and cones at the end. 1: Djurso; 2: Lermontovskaja Skala; 3: Mokraja Balka; 4: Kumbulta; 5: Kabardino-Balkaria; 6: Sakharnaja Golovka; 7: district of Glukhov; 8: Ksizovo; 9: Novoslavka 10: Alynkazgan. Due to the scale of the map, localization of sites is approximate. 


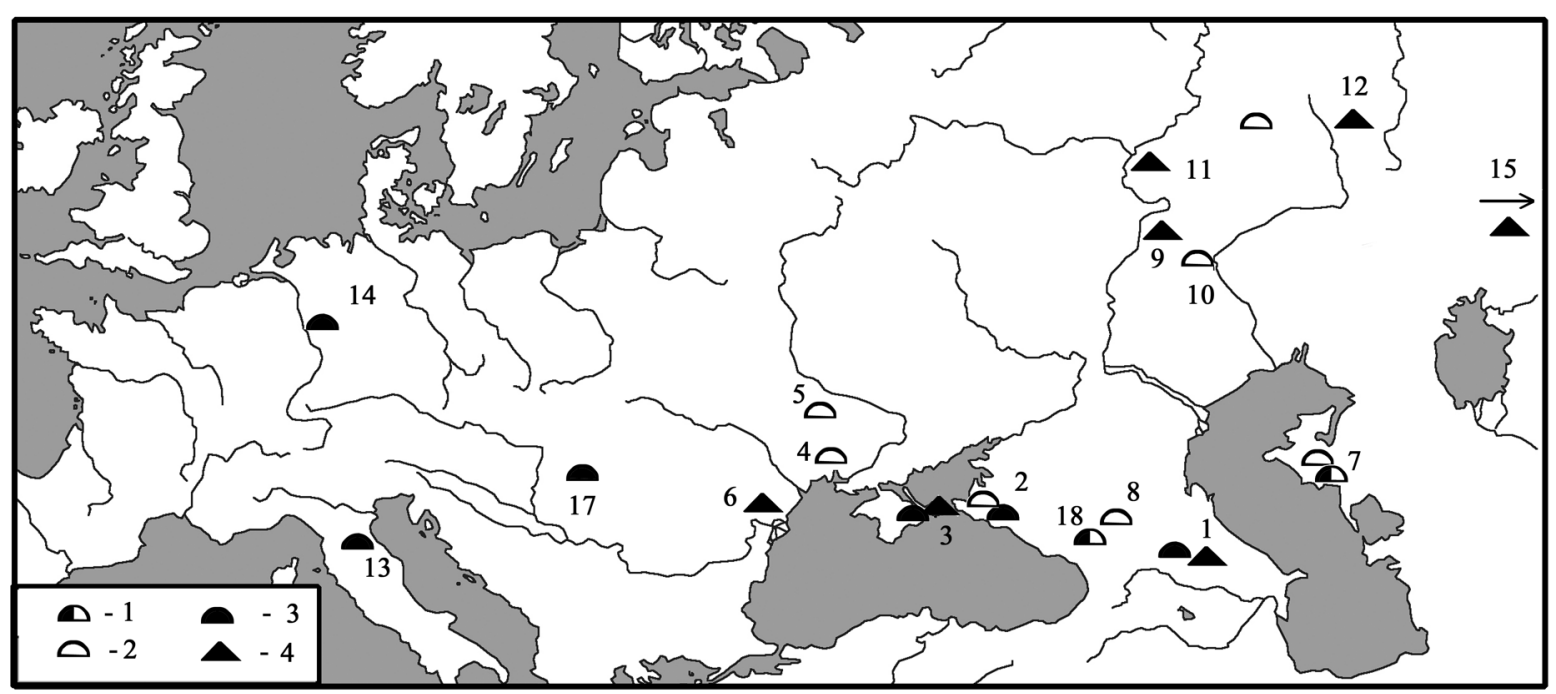

Рис. 7. Карта распространения металлических седельных накладок. 1 - тип Засецкая 3-Ахмедов 3; 2: - тип Засецкая 4а,б-Ахмедов 4; 3: тип Засецкая 4в-Ахмедов 6-7; 4: тип Засецкая 1б-Ахмедов 5.

Находки: 1: Галайты; 2: Дюрсо; 3: Керчь; 4: Ольвия; 5: Бабичи; 6: Ялпуг; 7: Алтынказган; 8: Мокрая Балка; 9: Владимирское; 10: Шипово; 11: Коминтерн II; 12: Солончанка I; 13: Равенна; 14: Крефельд-Геллеп; 15: Боровое; 16: Уфа; 17: Шарвиз; 18: Лермонтовская Скала. Ввиду масштаба карты локализация памятников приблизительна.

Fig. 7. Map of the distribution of metal saddle appliques. 1 - type Zasetskaya 3 - Akhmedov 3; 2: - type Zasetskaya 4a, b - Akhmedov 4; 3: type Zasetskaya 4v - Akhmedov 6-7; 4: type Zasetskaya 1b - Akhmedov 5.

Finds: 1: Galayty; 2: Djurso; 3: Kerch; 4: Olbia; 5: Babichi; 6: Yalpug; 7: Altinkazgan;

8: Mokraja Balka; 9: Vladimirskoye; 10: Shipovo; 11: Komintern II; 12: Solonchanka I; 13: Ravenna; 14: Krefeld-Gellep; 15: Borovoe; 16: Ufa; 17: Sarviz; 18: Lermontovskaja Skala. Due to the scale of the map, the localization of the sites is approximate

\section{СПИСОК ЛИТЕРАТУРЫ}

1. Kazanski M., Mastykova A. Le Caucase $\mathrm{du}$ Nord et la région méditerranéenne aux 5 e- 6e siècles. A propos de la formation de la civilisation aristocratique barbare // Eurasia Antiqua. 1999. Bd. 5. S. 523-573.

2. Казанский М.M., Мастыкова В.A. Хронологические индикаторы древностей постгуннского времени на Северном Кавказе // Верхнедонской Археологический Сборник. 2010(2013). Вып. 5. С. 93-104.

3. Tejral $J$. Einhemische und Fremde. Das norddanubische Gebiet zur Zeit der Völkerwanderung. Brno: Archäologisches Institut AW CR, 2011. 466 S.

\section{REFERENCES}

1. Kazanski M., Mastykova A. Le Caucase du Nord et la région méditerranéenne aux $5 \mathrm{e}-6 \mathrm{e}$ siècles. A propos de la formation de la civilisation aristocratique barbare Eurasia Antiqua. Bd. 5 . 1999:523-573.

2. Kazanski MM., Mastykova VA. Chronological indicators of antiquities of the post-Hun time in the North Caucasus [Khronologicheskie indikatory drevnostei postgunnskogo vremeni na Severnom Kavkaze] Verkhnedonskoy Archeologicheskii Sbornik. 2010 (2013). Vol. 5:93-104 (In Russ.).

3. Tejral J. Einhemische und Fremde. Das norddanubische Gebiet zur Zeit der Völkerwanderung. Brno: Archäologisches Institut AW CR, 2011:466.

4. Kazanski MM., Mastykova VA. Horse equip- 
4. Казанский М.M., Мастыкова В.A. Конское снаряжение эпохи Великого переселения народов из Сёсдалы и его понто-дунайские параллели // Боспорские исследования. 2018. Т. 36. С. 118-142.

5.Ахмедов И.Р. Конский убор некрополей Цебельдинской долины (к истории сложения «понтийского» стиля узды в эпоху Великого переселения народов) // II Городцовские чтения / Отв. ред. И.В. Белоцерковская. М.: Государственный Исторический музей, 2005. C. 240-253.

6. Ахмедов И.Р. Новые материалы к истории престижной узды Восточной Европы гуннского и постгуннсокго времени // Гунны, готы и сарматы между Волгой и Дунаем / Отв. ред. А.Г. Фурасьев. СанктПетербург: Факультет филологии и искусства СПбГУ, 2009. С. 152-166.

7. Дмитриев А.В. Погребения всадников и боевых коней в могильнике эпохи переселения народов на p. Дюрсо близ Новороссийска // Советская Археология. 1979. № 4. C. 212-229.

8. Рунич А.П. Захоронение вождя эпохи раннего средневековья из Кисловодской котловины // Советская Археология. 1976. № 3. C. 256-266.

9. АФанасъев Г.Е., Рунич А.П. Мокрая Балка. Вып. 1. Дневник раскопок. М.: Научный мир, 2001. $252 \mathrm{c}$.

10. Амброз А.К. Хронология древностей Северного Кавказа. М.: Наука, 1989. - 134 с.

11. Баранов И.А. Таврика в эпоху раннего средневековья. Киев: Наукова думка, 1990. $168 \mathrm{c}$.

12. Казанский M.M. Престижные находки и центры власти постгуннского времени в Поднепровье // Stratum plus. 2018. № 4. C. 83-118.

13. Обломский А.М., Козмирчук И.А. Могильник гуннского времени Ксизово-19 // Острая Лука Дона в древности. Археологический комплекс памятников гуннского времени у с. Ксизово (конец IV-V в.) / Отв. ред. А.М. Обломский. М.: Институт Археологии РАН, 2015. С. 134-164.

14. Валиев P.P. Новый памятник «коминтерновского типа» именьковской культуры // Археология евразийских степей. 2018. Вып. 1. С. 211-226.

15. Астафъев А.Е., Богданов Е.С. ment of the era of the Great Migration from Sösdala and its Ponto-Danube parallels Bosporian Researchs. 2018; (36):118-142(In Russ.).

5. Akhmedov IR. Horse dressing of necropolises of the Tsebelda valley (to the empire of addition of the "Pontic" style of rein in the era of the Great Migration) [Konskii ubor nekropolei Tsebel'dinskoi doliny (k ictorii slozheniya «pontiiskogo» stilya uzdy v epokhu Velikogo pereseleniya narodov)] II Gorodtsov readings / Ed. I.V. Belotserkovskaya. Moscow: State Historical Museum, 2005:240-253. (In Russ.).

6. Akhmedov IR. New materials on the history of the prestigious reins of Eastern Europe of the Hunnic and post-Hunnic times [Novye materialy $\mathrm{k}$ istorii prestizhnoi uzdy Vostochnoi Evropy gunnskogo i postgunnsokogo vremeni] Huns, Goths and Sarmatians between the Volga and the Danube [Gunny, goty i sarmaty mezhdu Volgoi i Dunaem]/ Ed. A.G. Furasiev. - St. Petersburg: Faculty of Philology and Art, St. Petersburg State University, 2009:152-166. (In Russ.).

7. Dmitriev AV. Burials of riders and war horses in the burial ground of the era of the resettlement of peoples on the river. Dyourso near Novorossiysk [Pogrebeniya vsadnikov i boevykh konei v mogil'nike epokhi pereseleniya narodov na r. Dyurso bliz Novorossiiska] Soviet Archeology. 1979(4):212-229. (In Russ.).

8. Runich AP. The burial of the leader of the early Middle Ages from the Kislovodsk depression [Zakhoronenie vozhdya epokhi rannego srednevekov'ya iz Kislovodskoi kotloviny] Soviet Archeology. 1976(3):256-266. (In Russ.).

9. Afanasyev GE., Runich AP. Mokraya Balka. Vol. 1. Excavation diary. Moscow: Nauchnyi mir, 2001:252. (In Russ.).

10. Ambroz AK. Chronology of antiquities of the North Caucasus [Khronologiya drevnostei Severnogo Kavkaza]. Moscow: Nauka, 1989: 134. (In Russ.).

11. Baranov IA. Taurica in the early Middle Ages. [Tavrika $v$ epokhu rannego srednevekov'ya]. Kiev: Naukova Dumka, 1990:168. (In Russ.).

12. Kazanski MM. Prestigious finds and power centers of the post-Hun time in the Dnieper [Prestizhnye nakhodki i tsentry vlasti postgunnskogo vremeni v Podneprov'e] Stratum plus. 2018(4):83118. (In Russ.).

13. Oblomsky AM., Kozmirchuk IA. The burial ground of the Hunnic time of Ksizovo-19 [Mogil'nik gunnskogo vremeni Ksizovo-19] Sharp Bow of the Don in antiquity. Acheological complex of monuments of the Hunnic time near the village. Ksizovo (end of the 4th - 5th centuries) [Ostraya Luka Dona $v$ drevnosti. Arkheologicheskii kompleks pamyatnikov gunnskogo vremeni u s. Ksizovo 
Ритуальные сооружения гуннского времени на Мангышлаке // Stratum plus. 2018. № 4. C. $347-470$.

16. Рунич А.П. Отчет о полевых работах в районе Кавминвод за 1973 год // Архив ИА РАН, 1973. Р.1. 5009.

17. Гунба M.M. Раскопки башни № 2 и помещения № 1 // Археологические исследования в Цебельде (результаты раскопок 1977 г.) / Ред. О. Лордкипанидзе. Тбилиси: Мецниереба, 1982. С. 27-39.

18. Воронов Ю.Н., Бгажба О.X. Материалы по археологии Цебельды. Тбилиси: Мецниереба, 1985. 212 с.

19. Трапш M.M. Труды. Том Третий. Культура цебельдинских некрополей. Тбилиси: Мецниереба, 1971. - 358 с.

20. Ахмедов И.Р. Удила // Гавритухин О.И., Обломский A.M. Гапоновский клад и его культурно-исторический контекст. М.: ИА РАН, Курский областной археологический музей, 1996. С. 41, 42.

21. Габуев T.A. Аланские княжеские курганы V в. н.э. у села Брут в Северной Осетии. Владикавказ: Институт истории и археологии РСО-Алания; Государственный музей искусства народов Востока. 2014. - 184 с.

22. Akhmedov I. New data about the origin of some constructive parts of the horse-harness of the Great Migration Period // International Connections of the Barbarians of the Carpathian Basin in the 1st-5th centuries A.D. / Eds. V. Istvánovits, V. Kulcsár. Aszód - Nyíregyháza: Jósa Anrás Museum - Osváth Gedeon Museum Foundation, 2001. P. 363-388.

23. Ахмедов И.Р. Уздечный набор из могильника Заречье 4 // Древности Евразии / Отв. ред. С.В. Демиденко, Д.В. Журавлев. М.: Государственный Исторический Музей, 1997. C. 261-268.

24. Дмитриев А.В. Раннесредневековые фибулы из могильника на р. Дюрсо // Древности эпохи Великого переселения народов V-VIII веков / Отв. ред. А.К. Амброз, И.Ф. Эрдели. М.: Наука, 1982. С. 69-107.

25. Текеев P.X-У. Отчет о работе археологической экспедиции КарачаевоЧеркесского областного краеведческого музея летом 1976 г. на Амгате. Архив Института Археологии РАН, 1976.

26. Рунич А.П. Раннесредневековые склепы Пятигорья // Советская Археология. (konets $I V-V v$.)]/ Ed. A.M. Oblomsky. Moscow: Institute of Archeology of the Russian Academy of Sciences, 2015:134-164. (In Russ.).

14. Valiev RR. A new site of the "Komintern type" of the Imenkovskaya culture [Novyi pamyatnik «kominternovskogo tipa» imen'kovskoi kul'tury] Archeology of the Eurasian steppes [Arkheologiya evraziiskikh stepei]. 2018(1):211-226. (In Russ.).

15. Astafiev AE., Bogdanov ES. Ritual constructions of the Hunnic time on Mangyshlak [Ritual'nye sooruzheniya gunnskogo vremeni na Mangyshlake] Stratum plus. 2018(4):347-470. (In Russ.).

16. Runich AP. Report on field work in the Kavminvod area for 1973 [Otchet o polevykh rabotakh v raione Kavminvod za 1973 god] Archive of the Institute of Archeology of the Russian Academy of Sciences. 1973:(1):5009. (In Russ.).

17. Gunba MM. Excavations of tower No. 2 and premises No. 1 [Raskopki bashni № 2 i pomeshcheniya № 1] Archaeological research in Tsebelda (results of excavations of 1977) / Ed. O. Lordkipanidze. Tbilisi: Metsniereba: 1982:27-39. (In Russ.).

18. Voronov YuN., Bgazhba OKh. Materials on the archeology of Tsebelda [Materialy po arkheologii Tsebel'dy.]. Tbilisi: Metzniereba, 1985:212. (In Russ.).

19. Trapsh MM. Proceedings. Volume Three. The culture of the Zebkldin necropolises. Tbilisi: Metsniereba, 1971:358. (In Russ.).

20. Akhmedov IR. Udila Gavritukhin O.I., Oblomsky AM., Gaponovsky treasure and its cultural and historical context. Moscow: Institute of Archaeology of of the Russian Academy of Sciences, Kursk Regional Archaeological Museum, 1996: 41, 42. (In Russ.).

21. Gabuev TA. Alan princely mounds of the $5^{\text {th }}$ century AD near the village of Brut in North Ossetia [Alanskie knyazheskie kurgany V v. n.e. u sela Brut v Severnoi Osetii]. Vladikavkaz: Institute of History and Archeology of North Ossetia-Alania; State Museum of Oriental Art. 2014:184. (In Russ.).

22. Akhmedov I. New data about the origin of some constructive parts of the horse-harness of the Great Migration Period International Connections of the Barbarians of the Carpathian Basin in the 1st5th centuries A.D. / Eds. V. Istvánovits, V. Kulcsár. - Aszód - Nyíregyháza: Jósa Anrás Museum - Osváth Gedeon Museum Foundation, 2001:363-388.

23. Akhmedov IR. Bridle set from the burial ground Zarechye 4 [Uzdechnyi nabor iz mogil'nika Zarech'e 4] Antiquities of Eurasia / Eds. S.V. Demidenko, D.V. Zhuravlev. Moscow: State Historical Museum, 1997:261-268. (In Russ.).

24. Dmitriev AV. Early medieval brooches from the burial ground on the river. Dyourso [Rannesrednevekovye fibuly iz mogil'nika na $r$. 
- 1979. - № 1.- C. 232-247.

27. Абрамова М.П. Ранние аланы Северного Кавказа III - V вв. н.э. М.: Институт Археологии РАН, 1997. - 165 c.

28. Амброз А.К. Южные художественные связи населения Верхнего Поднепровья в VI в. // Древние славяне и их соседи / Отв. ред. Ю.В. Кухаренко. М.: Наука, 1970. С. 70-74.

29. Ковалевская В.Б. Поясные наборы Евразии IV-IX вв. Пряжки (Свод Археологических Источников Е1-2). М.: Наука, 1979. - 110 с.

30. Васильева, Е.Е., Ахмедов И.Р. Новое погребение аланской знати постгуннского времени из Кабардино-Балкарии // Социальная стратификация населения Кавказа в конце античности и начале средневековья: археологические данные / Отв. ред. А.В. Мастыкова. М.: Институт Археологии РАН, 2015. - С. 13-16.

31. Багаев M.X. Культура горной Чечни и Дагестана в древности и средневековье. VI в. до н.э. - XII в. н.э. М.: Наука, 2008. - 455 с.

32. Воронов Ю.Н. Могилы апсилов. Итоги исследований некрополя Цибилтума в 1977-1986 годах. Пушино: ОНТИ ПНЦ PAH, 2003. - $348 \mathrm{c}$.

33. Айбабин А.И. Хронология могильников Крыма позднеримского и раннесредневекового времени // Материалы по Археологии, Истории и Этнографии Таврии. 1990. Т. I. С. 3-86, 175-241.

34. MacGregor A.A. Summary Catalogue of the Continental Archaeological Collections, Collections (Roman, Iron Age, Migration Period, Early Medieval) of the Ashmolean Museum (BAR International Series S674). Oxford: B.A.R., 1997. - 288 p.

35. Гавритухин О.И., Обломский A.M. Гапоновский клад и его культурноисторический контекст. М.: Институт Археологии РАН, Курский областной археологический музей, 1996. - 296 с.

36. Ахмедов И.Р. Воинское погребение из могильника Борок II // Тверской Археологический Сборник. 2001. Вып. 4. Tом II. C. 111-119.

37. Ахмедов И.Р., Казанский М.М. После Аттилы. Киевский клад и его культурноисторический контекст // Культурные трансформации и взаимовлияния в Днепровском регионе на исходе римского
Dyurso] Antiquities of the era of the Great Migration of Peoples of the V-VIII centuries / Ed. A.K. Ambroz, I. Erdelyi . Moscow: Nauka, 1982: 69-107. (In Russ.).

25. Tekeev RX-U. Report on the work of the archaeological expedition of the Karachay-Cherkess Regional Museum of Local Lore in the summer of 1976 on Amgata [Otchet o rabote arkheologicheskoi ekspeditsii Karachaevo-Cherkesskogo oblastnogo kraevedcheskogo muzeya letom $1976 \mathrm{~g}$. na Amgate]. Archive of the Institute of Archeology of the Russian Academy of Sciences, 1976:P1-6143. (In Russ.).

26. Runich AP. Early medieval crypts of the Pyatigorsk [Rannesrednevekovye sklepy Pyatigor'ya] Soviet Archeology. 1979(1):232-247. (In Russ.).

27. Abramova MP. Early Alans of the North Caucasus III-V centuries. AD Moscow: Institute of Archeology of the Russian Academy of Sciences, 1997:165. (In Russ.).

28. Ambroz AK. Southern artistic ties of the population of the Upper Dnieper in the VI century. [Yuzhnye khudozhestvennye svyazi naseleniya Verkhnego Podneprov'ya v VI v.] Ancient Slavs and their neighbors [Drevnie slavyane i ikh sosedi] / Ed. Yu.V. Kuharenko. Moscow: Nauka, 1970:70-74. (In Russ.).

29. Kovalevskaya VB. Belt sets of Eurasia IVIX centuries. Buckles (Corpus of Archaeological Sources, E1-2) [Poyasnye nabory Evrazii IV-IX vv. Pryazhki (Svod Arkheologicheskikh Istochnikov E12)]. Moscow: Nauka, 1979.:110. (In Russ.).

30. Vasilieva EE., Akhmedov IR. A new burial of the Alanian nobility of the Ostgunns time from Kabardino-Balkaria [Novoe pogrebenie alanskoi znati postgunnsokogo vremeni iz KabardinoBalkarii] Social stratification of the Caucasian population at the end of antiquity and the beginning of the Middle Ages: archaeological data [Sotsial'naya stratifikatsiya naseleniya Kavkaza $v$ kontse antichnosti $i$ nachale srednevekov'ya: arkheologicheskie dannye]/ Ed. A.V. Mastykova. Moscow: Institute of Archeology of the Russian Academy of Sciences, 2015:13-16. (In Russ.).

31. Bagaev MKh. The culture of mountain Chechnya and Dagestan in antiquity and the Middle Ages. VI century BC. - XII century AD [Kul'tura gornoi Chechni i Dagestana $v$ drevnosti i srednevekov'e. VI v. do n.e. - XII v. n.e.] Moscow: Nauka, 2008:455. (In Russ.).

32. Voronov YuN. Graves of the Apsils. The results of studies of the necropolis of Tsibiltum in 19771986 [Mogily apsilov. Itogi issledovanii nekropolya Tsibiltuma v 1977-1986 godakh.]. Pushino: ONTI PNC of the Russian Academy of Sciences, 2003:348. (In Russ.).

33. Aybabin A.I. Chronology of the Crimean cemeteries of the late Roman and early Medieval time [Khronologiya mogil'nikov Kryma pozdnerimskogo 
времени и в раннем средневековье / Отв. ред. В.М. Горюнова, О.А., Щеглова. СанктПетербург: Петербургское Востоковедение, 2004. C. 168-202.

38. Старостин П.Н. Памятники именьковской культуры (Свод Археологических источников Д1-32). М.: Наука 1967. - 100 с.

39. Левина Л.М. Раскопки могильников в окрестностях городищ Беданк-асар, Косacap и Томпак-асар // Низовья Сырдарьи в древности. Вып. III. Джетасарская культура. Ч. 2. Могильники Томпакасар и Косасар / Отв. ред. С.А. Трудновская. М.: Институт этнологии и антропологии РАН, 1993. С. 32-193.

40. Левина Л.М. Низовья Сырдарьи в древности. Вып. IV. Джетыасарская культура. Ч. 3-4. Могильники Алтынасар 4. М.: Институт этнологии и антропологии PAH, 1994. - $312 \mathrm{c}$.

41. Рунич А.П. Отчет о полевых исследованиях в районе Кавминвод за 1963 год // Архив Института Археологии РАН. 1963. Р1-2694.

42. Афанасъев Г.Е., Рунич А.П. Могильник № 1 у Лермонтовской Скалы близ г. Кисловодска // Советская археология. 1970. № 4. C. 222-227.

43. Казанский M.M. Седло из «княжеской» находки постгуннского времени в Галайты (Чечня): параллели и датировка // Археологическое наследие Кавказа: актуальные проблемы изучения и сохранения. XXXI Крупновские чтения. Материалы Международной научной конференции, посвященной 50-летию Крупновских чтений и 50-летию Дербентской археологической экспедиции. Махачкала, 20-25 апреля 2020 г. / Отв. ред. М.С. Гаджиев. Махачкала: МавраевЂ, 2020. C. $352-354$.

44. Засецкая И.П. Культура кочевников южнорусских степей в гуннскую эпоху (конец IV-V в.). Санкт-Петербург: Эллипс, Лтд., 1994. - 223 с.

45. Засецкая И.П. Классификация обкладок ленчиков седла V - первой половины VI в. // Засецкая, И.П., Казанский, М.М., Ахмедов, И.Р., Минасян, Р.С. Морской Чулек. Погребения знати из Приазовья и их место в истории племен i rannesrednevekovogo vremeni] Materials on Archeology, History and Ethnography of Tavria. 1990(I):3-86,175-241. (In Russ.).

34. MacGregor AA. Summary Catalogue of the Continental Archaeological Collections, Collections (Roman, Iron Age, Migration Period, Early Medieval) of the Ashmolean Museum (BAR International Series S674). Oxford: B.A.R., 1997:288.

35. Gavritukhin OI., Oblomsky AM. Gaponovo treasure and its cultural and historical context [Gaponovskii klad $i$ ego kul'turno-istoricheskii kontekst]. Moscow: Institute of Archeology of the Russian Academy of Sciences, Kursk Regional Archaeological Museum, 1996: 296. (In Russ.).

36. Akhmedov IR. Military burial from the burial ground Borok II [Voinskoe pogrebenie iz mogil'nika Borok II] Tver Archeological Collection [Tverskoi Arkheologicheskii Sbornik]. 2001(4, II):111-119. (In Russ.).

37. Akhmedov IR., Kazanski MM. After Attila. The Kiev treasure and its cultural and historical context [Posle Attily. Kievskii klad i ego kul'turnoistoricheskii kontekst] Cultural transformations and mutual influences in the Dnieper region at the end of the Roman time and in the early Middle Ages [Kul'turnye transformatsii $i$ vzaimovliyaniya $v$ Dneprovskom regione na iskhode rimskogo vremeni i v rannem srednevekov'e]/ Ed. V.M. Goryunova, O.A., Scheglova. St. Petersburg: Petersburg Oriental Studies, 2004:168-202. (In Russ.).

38. Starostin PN. Sites of Imenkovskaya culture (Corpus of Archaeological Sources D132) [Pamyatniki imen'kovskoi kul'tury (Svod Arkheologicheskikh istochnikov D1-32)]. Moscow: Nauka, 1967:100. (In Russ.).

39. Levina LM. Excavations of burial grounds in the vicinity of the sites of Bedank-asar, Kosasar and Tompak-asar [Raskopki mogil'nikov $\mathrm{v}$ okrestnostyakh gorodishch Bedank-asar, Kos-asar i Tompak-asar] The lower reaches of the Syr Darya in antiquity. Vol. III. Jetasar culture. [Nizov'ya Syrdar'i $v$ drevnosti. Vyp. III. Dzhetasarskaya kul'tura. Ch. 2. Mogil'niki Tompakasar i Kosasar ] Part 2. Tombs of Tompakasar and Kosasar / Ed. S.A. Trudnovskaya. Moscow: Institute of Ethnology and Anthropologyof the Russian Academy of Sciences, 1993:32-193. (In Russ.).

40. Levina LM. The lower reaches of the Syr Darya in antiquity. Issue IV. Jetyasar culture. Part 3-4. Graves Altynasar 4 [Nizov'ya Syrdar'i v drevnosti. Vyp. IV. Dzhetyasarskaya kul'tura. Ch. 3-4. Mogil'niki Altynasar 4.]. Moscow Institute of Ethnology and Anthropologyof the Russian Academy of Sciences 1994: 312. (In Russ.).

41. Runich AP. Report on field research in the Kavminvod area for 1963. [Otchet o polevykh 
Северного Причерноморья в постгуннскую эпоху. Санкт-Петербург: Государственный Эрмитаж, 2007. С. 142-146.

46. Ахмедов И.Р. Металлические детали декора жестких седел Восточной Европы гуннского и постгуннского времени. К изучению вопросов происхождения и классификации // Евразия в скифосарматское время. Памяти Ирины Ивановны Гущиной / Отв. ред. Д.В. Журавлев, К.Б. Фирсов. М.: Государственный Исторический Музей, 2012. С. 19-48.

47. Рунич А.П. Отчет о полевых исследованиях в районе Кавминвод за 1962 год // Архив Института Археологии РАН. 1962. Р1-2454.

48. Астафъев А.Е., Богданов E.C. Парадное седло из Альынказгана (полуостров Мангышлак, Казахстан) // Ахеология, Этнография и Антропология Евразии. 2015. Т. 3. № 4. С. 72-84.

49. Багаев M.X., Даутова P.A. Галайтинский клад в контексте темы средневековых вождеств на Северном Кавказе // Раннегосударственные образования и «княжеская» культура на Северном Кавказе в конце античности начале средневековья. Тезисы докладов Международного научного семинара, Махачкала, 13-17 ноября 2013 г. / Отв. ред. А.В. Мастыкова. М.: Институт Археологии $\mathrm{PAH}$, 2013. C. 7-9.

50. Périn $P$. Les tombes des «chefs» $\mathrm{du}$ début de l'époque mérovingienne // La noblesse romaine et les chefs barbares du IIIe au VIIe siècle / Dir. F. Vallet, M. Kazanski. Saint-Germain-en-Laye: Association française d'archéologie méroingienne, 1995. P. 247-301.

51. Wieczorek A., Perin P., von Welck K., Menghin W. (Hrsg.), Die Franken. Wegbereiter Europas. Mainz: Verlag Philipp von Zabern, 1996. - 1143 S.

52. Bierbrauer V. Die ostgotischen Grabund Schatzfunde in Italien. Spoleto: Centro Italiano di Studi sull'Alto Medioevo, 1975. - 380 S.

53. Alföldi A. Funde aus der Hunnenzeit und ihre ethnische Sonderung. Budapest: Magyar Nemzeti Múzeum, 1932. - 90 S.

54. Kleemann $J$. Bemerkungen zum Cloisonnierten Goldbleschlag vom Sárvíz // Archaeologiai Értesítő. 2007. Vol. 132. S. 123- issledovaniyakh $v$ raione Kavminvod za 1963 god] Archive Institute of Archeology aof the Russian Academy of Sciences, 1963:P1-2694. (In Russ.).

42. Afanasyev GE., Runich AP. Burial ground No. 1 near Lermontovskaya Skala near the city of Kislovodsk [Mogil'nik № 1 u Lermontovskoi Skaly bliz g. Kislovodska] Soviet Archeology. 1970(4):222227. (In Russ.).

43. Kazanski MM. Saddle from the "princely" find of the post-Hunnic time in Galayty (Chechnya): parallels and dating [Sedlo iz «knyazheskoi» nakhodki postgunnskogo vremeni v Galaity (Chechnya): paralleli i datirovka] Archaeological Heritage of the Caucasus: Actual Problems of Study and Preservation. XXXI Krupnovsky readings. Materials of the International scientific conference dedicated to the 5oth anniversary of the Krupnovsky readings and the 5oth anniversary of the Derbent archaeological expedition. Makhachkala, April 2025, 2020 / Ans. ed. M.S. Gadzhiev. Makhachkala: Mavraev, 2020:352-354. (In Russ.).

44. Zasetskaya IP. Culture of nomads of the southern Russian steppes in the Hunnic era (end of IV-V century) [Kul'tura kochevnikov yuzhnorusski$k h$ stepei $v$ gunnskuyu epokhu (konets $I V-V v$.)]. St. Petersburg: Ellipse, Ltd., 1994:223. (In Russ.).

45. Zasetskaya IP. Classification of cover plates for saddle seats of the fifth - first half of the sixth centuries [Klassifikatsiya obkladok lenchikov sedla $\mathrm{V}$ - pervoi poloviny VI v.] Zasetskaya I.P., Kazanski M.M., Akhmedov I.R., Minasyan R.S. Morskoï Chulek. Burials of nobles from the Sea of Azov and their place in the history of the tribes of the Northern Black Sea Region in the post-Hunnic era. St. Petersburg: State Hermitage Museum, 2007:142-146. (In Russ.).

46. Akhmedov IR. The metal details of the decor of the hard saddles of Eastern Europe of the Hunnic and post-Hunnic times to the study of questions of origin and classification [Metallicheskie detali dekora zhestkikh sedel Vostochnoi Evropy gunnskogo i postgunnskogo vremeni. $\mathrm{K}$ izucheniyu voprosov proiskhozhdeniya i klassifikatsii] Eurasia in the Scythian-Sarmatian time. In memory of Irina Ivanovna Gushchina [Evraziya $v$ skifo-sarmatskoe vremya. Pamyati Iriny Ivanovny Gushchinoi]/ Ed. D.V. Zhuravlev, K. B. Firsov. Moscow: State Historical Museum, 2012:19-48. (In Russ.).

47. Runich AP. Report on field research in the Kavminvod area for 1962 [Otchet o polevykh issledovaniyakh $v$ raione Kavminvod za 1962 god]. Archive of the Institute of Archeology of the Russian Academy of Sciences, 1962:P1-2454. (In Russ.).

48. Astafiev AE., Bogdanov ES. The main saddle from Alynkazgan (Mangyshlak Peninsula, Kazakhstan) [Paradnoe sedlo iz Al'ynkazgana (poluostrov Mangyshlak, Kazakhstan)] Acheology, Ethnogra- 
141.

55. Магомедов М.Г. Образование Хазарского каганата. М.: Наука, 1983. - 224 с.

56. Kazanski $M$. Deux appliques de selle post-hunnique provenant de Jalpug (Delta du Danube) : parallèles et datation // Studia Romana et Mediævalia Europænsia. Miscellanea in honorem annos LXXXV peragentis Professoris emeriti Dan Gh. Teodor oblata / Eds. D. Aparaschivei, G. Bilavschi. Bucureşti: Editura Academiei Române; Brăila: Editura Istros a Muzeului Brăilei „Carol I”, 2018. P. 169-187.

57. Казаков Е.П. Коминтерновский II могильник в системе древностей эпохи тюркских каганатов // Культуры евразийских степей второй половины I тысячелетия н.э. (вопросы хронологии) / Отв. ред. Д.А. Сташенков. Самарский областной историко-краеведческий музей им. П.В. Алабина. Самара, 1998. С. 97-150.

58. Таиров А.Д. (отв. ред.) Курган c «усами» Солончанка I. Челябинск: Челябинский государственный университет, 1999. - $152 \mathrm{c}$.

59. Werner J. Beiträge zur Archäologie des Attila-Rechies. München: Verlag der Bayerischen Akademie der Wissenschaften, 1956. $-138 \mathrm{~S}$.

6о. Храпунов И.Н. Казанский М.М. Погребения эпохи переселения народов в могильнике Нейзац // Храпунов (отв. ред.), Крым в сарматскую эпоху (II в. до н.э. - IV в.н.э.). 2016. T. II. C. 194-229.

61. Мастыкова А.B. Некоторые элементы женского убора оседлого населения пограничья степи в эпоху Великого переселения народов: миграция или мода? // Stratum plus. 2020. № 5. - в печати.

62. Прокопий из Кесарии. Война с готами / Перевод С.П. Кондратьева. М.: Издательство Академии Наук СССР, 1950. $516 \mathrm{c.}$

63. Иордан. О происхождении и деяниях готов «Getica» / Вступительная статья, перевод, комментарий Е.Ч. Скржинской. Санкт-Петербург: Алатейя, 2001.- 512 c.

64. Свод древнейших письменных известий о славянах. T. I. (I-VI в.) // Сост. Л.А. Гиндин, С.А. Иванов, Г.Г. Литаврин. М.: Институт славяноведения и балканистики phy and Anthropology of Eurasia. 2015;3(4):72-84. (In Russ.).

49. Bagaev MKh., Dautova RA. The Galaity treasure in the context of the theme of medieval chiefdoms in the North Caucasus [Galaitinskii klad v kontekste temy srednevekovykh vozhdestv na Severnom Kavkaze] Early state formations and "princely" culture in the North Caucasus at the end of antiquity - the beginning of the Middle Ages. Abstracts of the International Scientific Seminar, Makhachkala, November 13-17, 2013 [Раннегосударственные образования и «княжеская» культура на Северном Кавказе в конце античности - начале средневековья. Тезисы докладов Международного научного семинара] / Ed. A.V. Mastykova. Moscow: Institute of Archeology of the Russian Academy of Sciences, 2013: 7-9. (In Russ.).

50. Périn P. Les tombes des «chefs» du début de l'époque mérovingienne La noblesse romaine et les chefs barbares du IIIe au VIIe siècle / Dir. F. Vallet, M. Kazanski. - Saint-Germain-en-Laye : Association française d'archéologie méroingienne, 1995:247301.

51. Wieczorek A., Perin P., von Welck K., Menghin W. (Hrsg.), Die Franken. Wegbereiter Europas. Mainz: Verlag Philipp von Zabern, 1996:1143 S.

52. Bierbrauer V. Die ostgotischen Grab- und Schatzfunde in Italien. Spoleto: Centro Italiano di Studi sull'Alto Medioevo, 1975:380.

53. Alföldi A. Funde aus der Hunnenzeit und ihre ethnische Sonderung. Budapest: Magyar Nemzeti Múzeum, 1932:90.

54. Kleemann J. Bemerkungen zum Cloisonnierten Goldbleschlag vom Sárvíz Archaeologiai Értesító. 2007(132):123-141.

55. Magomedov MG. The formation of the Khazar Khaganate [Obrazovanie Khazarskogo kaganata]. Moscow: Nauka, 1983:224. (In Russ.).

56. Kazanski M. Deux appliques de selle posthunnique provenant de Jalpug (Delta du Danube) : parallèles et datation Studia Romana et Mediævalia Europænsia. Miscellanea in honorem annos $L X X X V$ peragentis Professoris emeriti Dan Gh. Teodor oblata / Eds. D. Aparaschivei, G. Bilavschi. - Bucureşti: Editura Academiei Române; Brăila: Editura Istros a Muzeului Brăilei „Carol I”, 2018:169- 187.

57. Kazakov EP., Kominternovsky II burial ground in the system of antiquities of the era of Turkic Khanates [Kominternovskii II mogil'nik v sisteme drevnostei epokhi tyurkskikh kaganatov] Cultures of the Eurasian steppes of the second half of the 1st millennium A.D. (questions of chronology) [Kul'tury evraziiskikh stepei vtoroi poloviny I tysyacheletiya n.e. (voprosy khronologii)]/Ed. D. Stashenkov. Samara Regional Museum of History and Local Lore. P.V. Alabin, Samara:97-150. (In Russ.). 
PAH, 1994. - $472 \mathrm{c}$.

65. Свод древнейших письменных известий о славянах. Том II (VII-IX вв.) // Сост. С.А. Иванов, Г.Г. Литаврин, В.К. Ронин. М.: Институт славяноведения и балканистики РАН, 1995. - 590 с.

Статья поступила в редакцию 29.05.2020 2.
58. Tairov AD. (ed.), Barrow with a "mustache" Solonchanka I [Kurgan s «usami» Solonchanka I]. Chelyabinsk: Chelyabinsk State University. 1999:152. (In Russ.).

59. Werner J. Beiträge zur Archäologie des Attila-Rechies. München: Verlag der Bayerischen Akademie der Wissenschaften, 1956:138.

60. Khrapunov IN. Kazanski MM. Burials of the era of the migration of peoples in the cemetery of Neisets [Pogrebeniya epokhi pereseleniya narodov $\mathrm{v}$ mogil'nike Neizats] Khrapunov (ed.), Crimea in the Sarmatian era (II century BC - IV century $A D$ ). 2016(II):194-229. (In Russ.).

61. Mastykova AV. Some elements of the women's dress of the sedentary population of the borderland steppe in the era of the Great Migration: migration or fashion? [Nekotorye elementy zhenskogo ubora osedlogo naseleniya pogranich'ya stepi $\mathrm{v}$ epokhu Velikogo pereseleniya narodov: migratsiya ili moda?] Stratum plus. 2020(5): in print. (In Russ.).

62. Procopius of Caesarea, The War with the Goths / Translation by S.P. Kondratiev. Moscow: Publishing House of the Academy of Sciences of the USSR, 1950:516. (In Russ.).

63. Jordanes, "Getica" / Introductory article, translation, comment by E.Ch. Skrzhinsky. St. Petersburg, Alateya, 2001:512. (In Russ.).

64. Corpus of ancient written testimonials about the Slavs. Volume I (I-VI centuries) // Eds. L.A. Gindin, S.A. Ivanov, G.G. Litavrin. Moscow: Institute of Slavic Studies and Balkan Studies of the Russian Academy of Sciences, 1994:472 p. (In Russ.).

65. Corpus of ancient written testimonials about the Slavs. Volume II (VII-IX centuries) // Eds. S.A. Ivanov, G.G. Litavrin, V.K. Ronin. Moscow: Institute of Slavic Studies and Balkan Studies of the Russian Academy of Sciences, 1995:590. (In Russ.). 